\title{
Rethinking Modes of Political Influence: Catherine de' Medici and her Female Political Network
}

Kelly A. Benner

West Virginia University

Follow this and additional works at: https://researchrepository.wvu.edu/etd

\section{Recommended Citation}

Benner, Kelly A., "Rethinking Modes of Political Influence: Catherine de' Medici and her Female Political Network" (2011). Graduate Theses, Dissertations, and Problem Reports. 789.

https://researchrepository.wvu.edu/etd/789

This Thesis is protected by copyright and/or related rights. It has been brought to you by the The Research Repository @ WVU with permission from the rights-holder(s). You are free to use this Thesis in any way that is permitted by the copyright and related rights legislation that applies to your use. For other uses you must obtain permission from the rights-holder(s) directly, unless additional rights are indicated by a Creative Commons license in the record and/ or on the work itself. This Thesis has been accepted for inclusion in WVU Graduate Theses, Dissertations, and Problem Reports collection by an authorized administrator of The Research Repository @ WVU. For more information, please contact researchrepository@mail.wvu.edu. 


\title{
Rethinking Modes of Political Influence: Catherine de' Medici and her Female Political Network
}

\author{
Kelly A. Benner \\ Thesis submitted to the \\ Eberly College of Arts and Sciences \\ at West Virginia University \\ in partial fulfillment of the requirements \\ for the degree of
}

\section{Master of Arts}

in

History

\author{
Matthew Vester, Ph.D., Chair \\ Katherine Aaslestad, Ph.D \\ Kathryn Staples, Ph.D. \\ Department of History
}

Morgantown, West Virginia

2011

Keywords: Catherine de' Medici, Female Patronage, Political Networks, Marguerite de Valois, Mary, Queen of Scots

Copyright 2011 Kelly A. Benner 


\begin{abstract}
ABTRACT
Rethinking Modes of Political Influence: Catherine de' Medici and her Female Political Network

Kelly A. Benner

Though previous studies on the political career of Catherine de' Medici have been male-centric, focusing primarily on Catherine's relationships with her sons and male noblemen, it is the contention of this thesis that Catherine amassed a female-based political network during her tenure as Queen mother. Comprised of both her female relatives and the noblewomen that surrounded her at court, Catherine used this system of females to manipulate both domestic and foreign politics. The first chapter of this thesis will focus on Catherine's political purpose for her eldest and youngest daughters, Élisabeth de Valois (consort of Philip II of Spain) and Marguerite de Valois (first wife of Henri IV of France). The second chapter will next examine the role of Catherine's three daughters-in-law, Mary Stuart, Queen of Scots, Elisabeth of Austria, and Louise de Lorraine-Vaudémont within her political network. The final chapter will then concentrate on two members of Catherine's infamous "flying squadron," Louise de La Béraudière, also known as "la belle Rouhet" and Charlotte de Sauve respectively, and how the Queen mother utilized them to manage potentially troublesome noblemen at court.
\end{abstract}




\section{TABLE OF CONTENTS}

$\begin{array}{ll}\text { Abstract } & \text { ii } \\ \text { Abbreviations } & \text { iv } \\ \text { Chapter 1: Introduction } & 1 \\ \text { Chapter 2: The Daughters } & 10 \\ \text { Chapter 3: The Daughters-in-law } & 35 \\ \text { Chapter 4: The Flying Squadron } & 60 \\ \text { Chapter 5: The Conclusion } & 85 \\ \text { Bibliography } & 90\end{array}$ 


\section{ABBREVIATIONS}

CPS, Foreign

CPS, Foreign, BHO

CPS, Scotland

LCM
Calendar of State Papers, Foreign Series, of the Reign of Elizabeth

Calendar of State Papers, Foreign Series, of the Reign of Elizabeth from British History Online

Calendar of State Papers Relating to Scotland and Mary, Queen of Scots

Lettres de Catherine de Médicis 


\section{Chapter 1: Introduction}

Considering her comparatively low origins and the presence of affluent royal mistresses for much of her marriage to King Henri II, how did Queen Catherine de' Medici become one of the most dominant figures in sixteenth-century politics, especially when the "French monarchy was quite stingy allowing women in positions of political power"? ${ }^{1}$ The majority of scholarship on Catherine's political career after her husband's death contends, as historian Katherine Crawford so eloquently puts it, that Catherine was able to assume the reins of power through her utilization of "accepted notions of female behavior" and her "conformity with familiar and acceptable [gender] roles." ${ }^{2}$ In other words, it was her ability to utilize male conceptions of maternal protectiveness within male spheres of influence to control her male offspring and to manipulate male nobles that allowed her to gain political power during her sons' minorities.

At the same time, what about her relationship to the royal and noblewomen who surrounded her? My thesis will investigate whether Catherine de' Medici was able to use her network of female relations and noblewomen to extend her political influence during the reigns of her sons and to allow her to preserve her "authority" as they entered maturity. Though her use of female networks during her tenure as Queen mother was not as significant as her ability to control the men around her for political gain, this thesis will examine how these court women, who are often marginalized in the historiography of the period, were used by Catherine. Could they have helped mold international and domestic politics to benefit France and help prolong Catherine's own political influence?

As already implied, one of the most important contributions that this thesis can make to the scholarship on Catherine de' Medici's political career is that it could shed a different light on

\footnotetext{
${ }^{1}$ Katherine Crawford, "Catherine de Medici and the Performance of Political Motherhood," The Sixteenth Century Journal 31, 3 (Autumn 2000): 644.

${ }^{2}$ Ibid., 645.
} 
how Catherine accumulated and maintained political power. In addition to being depicted as "cold, cruel, calculating, treacherous and evil," much of the scholarship depicting Catherine's participation in French politics in the four centuries after her death was primarily concerned with Catherine's manipulation of her young sons during their minorities. ${ }^{3}$ Though N.M. Sutherland's scholarship on Catherine de' Medici during the 1970s did much to revise the menacing light in which Catherine had been depicted, it did little to alter the view on how Catherine had exercised her authority. ${ }^{4}$ In a 2003 essay, Margaret Hoogvliet, focused on how Catherine used architectural projects and court festivals both to legitimize and to attach a sense of kingly power to her sons whom she controlled. ${ }^{5}$ More recently, Katherine Crawford has asserted that Catherine's position as regent "rested above all on being a good mother" to her male offspring and used the "language of affection around motherhood to legitimize her regency." In short, Hoogvliet, like Crawford, implies that Catherine's power rested on her "natural authority over her sons." Recent biographers of Catherine de' Medici do little to elucidate how the Queen mother utilized the women around her for her own benefit. Relating Catherine's political career in a largely chronological format, Leonida Freida and Robert Knecht scarcely mention Catherine's daughters and female companions. ${ }^{8}$

\footnotetext{
${ }^{3}$ N.M. Sutherland, "Catherine De Medici: The Legend of the Wicked Italian Queen," The Sixteenth Century Journal 9, 2 (July 1978).

${ }^{4}$ Ibid., 56.

${ }^{5}$ Hoogvliet, Margriet. "Princely Culture and Catherine de Médicis," in Princes and Princely Culture, 1450-1650, ed. by Martin Gosman, Alasdair MacDonald, and Arie Johan Vanderjagt, vol. 1. (Leiden and Boston: Brill, 2003). Though the primary focus of this work is to examine how Catherine used court ceremonies and artistic and architectural projects to "legitimise her governing role" by presenting herself as "mother to her sons" (p. 129), Hoogvliet does dedicate a couple of paragraphs to the subject of the "official political functions" of Catherine's ladies-in-waiting on pg. 126.

${ }^{6}$ Katherine Crawford, Perilous Performances: Gender and Regency in Early Modern France (Cambridge, MA: Harvard University Press, 2004), 30, 38.

${ }^{7}$ Hoogvliet, "Princely Culture," 129.

${ }^{8}$ R.J. Knecht, Catherine de' Medici (New York, NY: Longman, 1998); Leonie Frieda, Catherine de Medici: Renaissance Queen of France (New York, NY: Harper Collins Publishers Inc., 2003).
} 
This thesis also proposes to examine how early modern women participated in clientage and dynastic networks, an issue that remains surprisingly under-studied. Of course, the subject of female-oriented kinship and patron-client systems is not necessarily a new topic of discussion within the historiography of the early modern period. In fact, as early as 1972, Nancy L. Roelker examined "networks of noble women" in which female court-style groups formed around a prominent noblewoman on the basis of blood, marriage, and social and religious ties. ${ }^{9}$ However, since Roelker's seminal article, that arguably "corrected the historical record by adding women to [early modern French] history," there have been comparatively few works concentrating on the subject of female networks specifically in France since its publication. ${ }^{10}$

Sharon Kettering, who wrote a multitude of works on client-patronage systems in sixteenth and seventeenth-century France, only published two pieces of scholarship focusing solely on the networks and patronage powers of prominent noblewomen, and these studies were primarily centered on economic, not political, patronage. ${ }^{11}$ According to Kettering, political patronage could only be distributed by royal women, which in retrospect, partially explains why there has been such a dearth in studies of political patronage amongst noblewomen. On the other hand, Penny Richard's more recent articles on the Guise women does touch upon the political activities of notable Leaguer females such as Anne d'Este and Catherine de Clèves, but, Richards describes their role as being more symbolic than material. ${ }^{12}$

\footnotetext{
${ }^{9}$ Nancy L. Roelker, "The Appeal of Calvinism to French Noblewomen in the Sixteenth Century," Journal of Interdisciplinary History 2, 4 (Spring 1972): 391-418; Joanne Baker, "Monasticism and Family Strategy: The Guises and Saint Pierre de Reims," The Sixteenth-Century Journal 28,4 (Winter 1997): 1091.

${ }^{10}$ Kristen B. Neuschel, "Noblewomen and War in Sixteenth-Century France," in Changing Identities in Early Modern France, ed. Michael Wolfe (Durham, NC: Duke University Press, 1997), 124.

${ }^{11}$ Sharon Kettering, "The Patronage and Power of Early Modern French Noblewomen," The Historical Journal 32, 4 (December 1989): 817-841; Sharon Kettering, "The Household Service of Early Modern French Noblewomen," French Historical Studies 20, 1 (Winter 1997): 55-85.

${ }^{12}$ Penny Richards, "The Guise Women: Politics, War and Peace," in Gender, Power and Privilege in Early Modern Europe, ed. Jessica Munns and Penny Richards (Harlow, UK: Pearson Education Limited, 2003), 168-9; Jessica
} 
Despite the paucity of scholarship on female patronage in early modern France, in the past ten years there have been several books and essays written on the subject of female networks and the role of women within aristocratic kinship systems. In a 1996 article, Joanne Baker focused on female social networks centered around the abbey of Saint Pierre de Reims, which was headed by a female member of the Guise family. Despite the fact that the Guise family was unable to reap the benefits of an arranged marriage when placing its female members within the abbey, Baker asserts that these women played a significant role in "family strategies and dynastic planning." ${ }^{, 13}$ In addition to raising the family's spiritual prestige, they also solidified the dynasty's presence within the Catholic Church. ${ }^{14}$ Four years later, Sara Chapman published her study of the Phelypeaux de Pontchartrain family during the reign of Louis XIV. Though women themselves could not hold public office, Chapman describes these females as having to "cultivate and maintain" their husbands' network of friends and political alliances. ${ }^{15}$

In terms of early modern French dynastic networks, two notable essays describe how family heads utilized female relations to help obtain their political goals. The first is Robert Oresko's study of the nieces of Jules Cardinal Mazarin. In addition to assuaging Mazarin's political dilemmas within France, Oresko's 1995 article describes the marital alliances brokered by Mazarin for his nieces as helping to strengthen France foreign policy, since the French monarchy did not have any princesses of marriageable age during his tenure at court. ${ }^{16}$ The second is Simon Hodson's short essay on the political and religious network forged by Louise de

\footnotetext{
Munns and Penny Richards, "Exploiting and Destabilizing Gender Roles: Anne d'Este,” French History 6, 2 (1992): 206-7.

${ }^{13}$ Ibid., 1091.

${ }^{14}$ Ibid., 1093-4.

${ }^{15}$ Sara Chapman, "Patronage as Family Economy: The Role of Women in the Patron-Client Network of the Phelypeaux de Pontchartran Family," French Historical Studies 24, 1 (Winter 2001): 17.

${ }^{16}$ Robert Oresko, "The Marriages of the Nieces of Cardinal Mazarin: Public Policy and Private Strategy in Seventeenth-Century Europe, in Frankreich im Europäischen Staatensystem der Frühen Neuzeit, ed. Rainer Babel (Sigmaringen,1995).
} 
Coligny, princess of Orange through the marriages of her stepdaughters. Concentrating on a sixteenth-century network that was both led by a French woman and held together by females, Hodson's 2007 essay describes Louise de Coligny as using the marital alliances of her female relations to realize her political and Pan-Calvinist goals. ${ }^{17}$

Despite the relative dearth of scholarship on political and clientage networks comprised of French women and centered on the sixteenth century, historians of other European regions, especially Great Britain, have made significant progress in explaining how female networks functioned during the early modern period. Within the field of British history, nearly every biography of so called great ladies, even those written by popular historians, have pages dedicated to the increased political patronage power of women at the Tudor court. Focusing on more serious scholarship, both Eric Ives's and John H. King's scholarship on Anne Boleyn and Katharine Parr respectively describes how these consorts were able to dispense political and clerical patronage to raise the prestige of their family and to help further their religious causes. ${ }^{18}$

Works on both royal and aristocratic female networks are likewise more numerous when centered on Great Britain. Though it is a more localized study, Melissa Franklin-Harkrider's account of Katherine Brandon, Duchess of Suffolk and the aristocracy of Lincolnshire concentrates to a degree on the role that Brandon's religious "circle" played in the expansion of Protestantism in England. ${ }^{19}$ Franklin-Harkrider's work is accompanied by Barbara Harris's scholarship on kinship networks among aristocratic women during the fifteenth and sixteenth-

\footnotetext{
${ }^{17}$ Simon Hodson, "The Power of Female Dynastic Networks: A Brief Study of Louise de Coligny, Princess of Orange, and her Stepdaughters," Women's History Review 16, 3 (July 2007): 335-351.

${ }^{18}$ Eric Ives, The Life and Death of Anne Boleyn (Malden, MA: Wiley-Blackwell, 2005); John H. King, "Patronage and Piety: Katharine Parri" in Silent but for the Word: Tudor Women as Patrons, Translators, and Writers of Religious Works, ed. Margaret P. Hannay (Kent, Ohio: Kent State University Press, 1985).

${ }^{19}$ Melissa Franklin Harkrider, Women, Reform and Community in Early Modern England: Katherine Willoughby, Duchess of Suffolk (Woodbridge, Rochester, NY: Boydell Press, 2008).
} 
centuries. ${ }^{20}$ There has also been resurgence of interest in the role of ladies-in-waiting, and their relationships to their mistresses at court, as exemplified by Anne Somerset's and Natalie Mears scholarship, in addition to Helen Payne's more recent essay on the political influence of women at the Jacobean court. ${ }^{21}$ Shifting from the British Isles to the Iberian Peninsula, Magdalena Sanchez's book on the political system forged by Maria, the dowager Holy Roman Empress, her daughter, the nun Margaret of the Cross, and her female relation Margaret of Austria, spouse of Philip III, is another prominent work of scholarship that focuses on how groups of early modern women could alter both domestic and foreign politics by working in concert with each other. ${ }^{22}$

In summary, Catherine de' Medici's acquisition of political influence has long been ascribed to her ability to control her young sons, as well as to her knack for utilizing accepted notions of maternity and femininity to help legitimate her regency to her male nobles. However, this thesis will examine whether Catherine de' Medici was also reliant on the females around her, most notably her daughters, daughters-in-law, and ladies-in-waiting to help maintain political authority as well as to benefit the domestic and foreign policy goals of the French crown. It will also perhaps also fill a hole in the historiography of early modern patron-client and kinship systems. The majority of those works that focus on the patronage power of women in early modern France are primarily centered on domestic and artistic patronage, and much of the scholarship on exclusively female networks is either focused on countries other than France, or not set in the sixteenth-century. My intent is that this present work will provide one of the first

\footnotetext{
${ }^{20}$ Barbara J. Harris, English Aristocratic Women, 1450-1550: Marriage and Family, Property and Careers (Oxford, UK: Oxford University Press, 2002); Barbara J. Harris, "Sisterhood, Friendship and the Power of English Aristocratic Women, 1450-1550," in Women and Politics in Early Modern England, 1450-1700, ed. James Daybell (Aldershot: Ashgate, 2004).

${ }^{21}$ Natalie Mears, "Politics in the Elizabethan Pricy Chamber: Lady Mary Sidney and Kat Ashley," in Women and Politics in Early Modern England, 1450-1700, ed. James Daybell (Aldershot: Ashgate, 2004); Helen Payne, "Aristocratic Women, Power, Patronage and Family Networks at the Jacobean Court, 1603-1635," in Women and Politics in Early Modern England, 1450-1700, ed. James Daybell (Aldershot: Ashgate, 2004). ${ }^{22}$ Magdalena S. Sánchez, The Empress, the Queen, and the Nun: Women and Power at the Court of Philip III of Spain (Baltimore, MD: Johns Hopkins University Press, 1998).
} 
extensive looks at how sixteenth-century female networks in France manipulated the course of national politics.

This thesis will be divided into three chapters, with each chapter dedicated to how Catherine's daughters, daughters-in-law, and finally her noblewomen figured into Catherine's political system. The first chapter will focus on how Catherine de' Medici used her daughters Élisabeth de Valois, Queen of Spain and Marguerite de Valois, Queen of Navarre and France, to both solidify her own power base and to rectify France's domestic and foreign policy troubles. Catherine de' Medici did not broker the marriage between her daughter Élisabeth and Philip II, King of Spain, however, Catherine certainly capitalized on Philip's fondness for Catherine's young and attractive daughter even after Élisabeth's death. Though the Queen mother's initial intentions for marrying Marguerite to Henri de Navarre did not pan out, Catherine used her youngest daughter as an intermediary between herself and the French Huguenot party, in an attempt to help mitigate tensions between Huguenots and Catholics after the St. Bartholomew's Day Massacre.

The second chapter will examine the often neglected relationships between Catherine de' Medici and her daughters-in-law, Mary Stuart, Queen of Scots, Elisabeth of Austria, and Louise de Lorraine-Vaudémont. Though typically understood to be enemies, this chapter will explore how Catherine de' Medici saw Mary Stuart as an integral component of her political network, even after Mary's imprisonment in England and despite Mary's connections with Catherine's greatest rivals, members of the house of Lorraine. Regardless of the fact that Charles IX's consort is so often ignored in the scholarship of the period, this thesis will likewise examine how Catherine may have attempted to use her familial relationship with Elisabeth of Austria to assuage the tensions between the French crown and the Austrian and Spanish Habsburgs. As for 
Louise de Lorraine-Vaudémont, the wife of Catherine's favorite son Henri III, this chapter will show how Catherine, despite being initially opposed to the match, sought, along with her son, to mitigate the strained relations between the troublesome Guise clan and the house of Valois using Louise's position as queen consort.

The final chapter will discuss the potential function that Catherine de' Medici's ladies-inwaiting had in the realization of Catherine's domestic political goals, especially in regard to keeping potentially troublesome noblemen in check. Known famously to history as the "escadron volant," or "flying squadron," Catherine de' Medici used this group of attractive lower-ranking noblewomen to seduce both troublesome noble grandees and disobedient male relatives to discourage these men in their rebellious ventures and make them more amendable to Catherine's political agenda. The two famous members of the "flying squadron" that will be included in this work will be Louise de la Béraudière, mistress of Antoine de Bourbon, king of Navarre and Charlotte de Beaune Semblançay, baroness of Sauve, mistress of Catherine's son (the duke of Alençon) and her son-in-law (Henri de Bourbon, King of Navarre).

In short, with this three-chapter thesis, which focuses on Catherine de' Medici's political relationship with her daughters, her daughters-in-law, her ladies-in-waiting respectively, my intent is to shed new light on how Catherine de' Medici, who is arguably one of the most powerful women of the early modern period, accumulated and exercised political authority. I also desire to draw greater attention to the existence female comprised political networks, and how they potentially altered the character of court politics during Catherine's tenure as queen mother and ultimately impacted the politics of that period.

Though scholarship on early modern networks has greatly expanded in the last few decades, the historiography of the subject is still largely dominated by works focusing on 
noblemen. Another salient problem is that those works that do concentrate on the sixteenthcentury female networks are either focused on Ultra-Catholic leaguer females, like the Guise women, or on influential protestant noblewomen such Jeanne d'Albret, Queen of Navarre and female relatives of the Admiral Gaspard de Coligny. In other words, very little attention is paid to arguably the most powerful female political system in sixteenth-century France, that of Catherine de' Medici. The absence of scholarship on Catherine's female political networks, and likewise how they were used during her tenure as Queen mother, can be explained in two ways. First, particularly in the case of the infamous "escadron volant," is that there is a lack of sources that indicate that Catherine used her female relations and noblewomen in unordinary ways. The second, and most important, is the tendency for historians to concentrate on Catherine's relationship with her sons and how she likewise used her sons to maneuver within male dominated political spheres. Of course, Catherine's sons played the most vital role in Catherine's ability to acquire and maintain political influence. However, as the examples of these aforementioned female will show, Catherine's ability to utilize the women around her also played an important part in the success of her political designs and in the preservation of her own authority 


\section{Chapter 1: Catherine's Daughters}

As already mentioned, this chapter examines the purpose Catherine had for her daughters within her political network and will focus specifically on Catherine's eldest and youngest daughters, Élisabeth, who would marry Philip II, king of Spain in 1559 and Marguerite, who would marry Henri de Bourbon, king of Navarre, respectively. Using primarily Catherine's published correspondence, which provides the most extensive, though at times overly sanitized, look at Catherine's respective political relationships with her daughters, the main focus of chapter will be to examine what domestic and foreign policy crises Catherine sought to avert with the presence of her daughter in their respective positions of power in foreign courts. It will likewise analyze how the mere presence of these two women, as a symbol of political amity between the French crown and the Spanish and Navaresse monarchies, may have induced their respective husbands to make friendly political gestures toward both the French monarch and the Queen mother. Though a degree of self-interest undoubtedly played a role in Élisabeth's and Marguerite's acquiescence to Catherine's political designs, it seems that this kinship-based political system that included Catherine's daughters was largely built upon sense of duty to Catherine and the French crown.

\section{Élisabeth de Valois: Queen of Spain}

Of Catherine de' Medici's daughters, it was undoubtedly Élisabeth, who despite her short life, would play the most significant role in the realization of her mother's foreign policy goals. The eldest of Catherine's daughters, Élisabeth was born on April 2, 1545 in the Château de Fontainebleau, and from the moment of her birth, there were already auspicious signs that the 
eldest "fille de France" would help bring political stability to the French realm and to Europe. ${ }^{23}$ Her birth coinciding with a peace agreement made between her grandfather François I and the English King Henry VIII, Henry VIII was made Élisabeth's godfather in a gesture of good faith on François I's part to strengthen the tenuous rapprochement between the English and French royal houses. According to that great chronicler of Valois court life Pierre de Bourdeille, better known as seigneur de Brantôme, the young and virtuous Élisabeth seemed destined to be a great lady, earning the admiration of the court, especially that of her father Henri II and her mother Catherine de' Medici, though it would later become quite evident that her younger sister Claude was the favorite daughter of Queen Catherine. ${ }^{24}$

Regardless of his wife's personal preferences, Henri II was astutely aware of his eldest daughter's potential for building cordial and mutually beneficial relations with other European powers. Since France was still at war with the Habsburg Empire, it was initially Henri II's great ambition to marry Élisabeth to the boy King of England, Edward VI, in an attempt to counterbalance Habsburg hegemony on the continent, which was currently suffocating France from all directions. ${ }^{25}$ Unfortunately for Henri II, Edward VI's premature death in 1553 not only squashed his marital aspirations for his eldest daughter, but also led to the accession of the halfSpanish Queen Mary Tudor, who abandoned the Anglo-French conciliatory policy favored by her half-brother Edward VI, and instead renewed friendly relations with her Habsburg relatives, culminating in a marriage between Charles V's heir Philip, prince of Asturias and herself. Despite the entrance of the English into the conflict on the side of the Empire, the Habsburg-

\footnotetext{
${ }^{23}$ Sylvène Édouard, Le corps d'une reine: Histoire singulière d'Élisabeth de Valois, 1546-1568 (Rennes : Presses Universitaires de Rennes, 2009), 17.

${ }^{24}$ Brantôme, Illustrious Dames, 137-8.

${ }^{25}$ Catherine de Medici to Bertrand de Salignac de la Mothe Fénélon, 13 September 1572, in Lettres de Catherine de Medici, ed. Hector de la Ferrière (Paris: Imprimerie Nationale, 1880-1943), vol. 4: 125.
} 
Valois Wars raged on for much of 1550s with both sides finally agreeing to sign a peace agreement in April 1559 at Cateau-Cambrésis.

As the wars concluded, Henri II arranged for his second eldest daughter Claude to marry Charles III, duke of Lorraine, even though Élisabeth was still unmarried. According to Brantôme, Henri II's lack of propriety in marrying off a younger daughter before the eldest disconcerted many of his courtiers. Upon being asked for his reasoning in this match, Henri II was supposed to have replied that his "daughter Élisabeth is such that a duchy is not for her to marry. She must have a kingdom." ${ }^{26}$ Regardless of whether or not this colorful anecdote actually occurred, it seems that Henri II's foresight in postponing Élisabeth's engagement would pay off in the long-term. A major turning point in the course of sixteenth-century international relations, the Peace of Cateau-Cambrésis ushered in a reconciliatory phase in Valois-Habsburg relations, which allowed Henri II to turn his attention towards eliminating a new menace, the spread of Protestantism. In order eradicate Calvinism from within his realm, Henri II needed to ensure that there would continue to be peace between himself and his once great enemy the Spanish monarch, so, Henri II resorted to a time-honored means of solidifying political alliances, arranging a marital alliance between his eldest daughter Élisabeth and the Spanish Habsburgs. ${ }^{27}$ In the initial negotiations, Élisabeth was at first offered up by Henri II as a potential bride for Don Carlos, prince of Asturias, and the eldest son of the recently crowned King Philip II. However, events necessitated that Philip take Élisabeth for himself since his wife, Mary Tudor, had died in 1558 and his son Don Carlos's physical and mental incapacities were becoming increasingly apparent at the Spanish court.

\footnotetext{
${ }^{26}$ Brantôme, Illustrious Dames, 138.

${ }^{27}$ Jean-Michel Ribera, Diplomatie et Espionnage: Les ambassadeurs du roi de France auprès de Philippe II du traité du Cateau-Cambresis (1559) a la mort de Henri III (1589). (Paris: Honoré Champion Éditeur, 2007), 362-3.
} 
Since the match between King Philip and her daughter Élisabeth was engineered during the reign of her husband, when she was a comparatively insignificant political figure due to the influence of Henri II's maitresse en titre, Diane de Poitiers, it is unlikely that Catherine had any considerable role in the marriage's fruition. However, as time would show, Catherine became one of the marriage's main beneficiaries. In July 1559, while jousting in a tournament celebrating the marriage between Élisabeth and the king of Spain, King Henri II was pierced through the eye with a lance and succumbed to his wounds a few days later, leaving his fifteenyear-old son, François, king of France. ${ }^{28}$ Despite Catherine's status as Queen Mother, the Guise enacted a swift "coup d'état" causing the duke of Guise and the cardinal of Lorraine to assume real power. ${ }^{29}$ With François II's death in 1560 and the accession of her second eldest son Charles IX, Catherine was better able to assert her position as Queen Mother and with the aid of her new ally Antoine de Bourbon, king of Navarre, the Queen Mother regent and the royal tutelle were able to push the Guise out of power. ${ }^{30}$ However, the house of Lorraine was still a force to be reckoned with, and though the king of Navarre had at least temporarily supplicated himself to Catherine, his younger brother Louis I de Bourbon, prince de Condé was making preparations for war against the regency. It was under these circumstances, that Élisabeth de Valois, now queen of Spain, became the cornerstone of Catherine's female network.

It is difficult to gauge Élisabeth's contribution to the machinations of Catherine de' Medici during the reign of François II, since the young boy's tenure as king lasted only one year and because much of the existing correspondence between Catherine and her daughter during this period deal with pleasantries and inquiries about one another's health. This is partially

\footnotetext{
${ }^{28}$ Knecht, Catherine de Medici, 57-8.

${ }^{29}$ Ibid., 60-61.

${ }^{30}$ Jean-Marie Constant. Les Guises (Paris: Hachette, 1984), 45.
} 
understandable, since at that time, the queen of Spain would have been only fourteen or fifteen years old. However, a few years into Charles IX's reign, Catherine's intended role for her eldest daughter within her political network is much more distinguishable. There are essentially three ways one can measure how Catherine attempted to use her familial connection to the Queen of Spain to realize her own political desires. The first is to examine positive conciliatory measures made by the King of Spain to the French crown during the length of his marriage to Queen Élisabeth. The second is to analyze the political issues discussed within Catherine and Élisabeth's correspondence, with the understanding that Élisabeth would then either act as an advocate for Catherine's request or as an apologist for Catherine's political initiatives. The third and final means of discerning Catherine's role for Élisabeth in her political network is to examine the requests made by Catherine for Élisabeth to intercede on Catherine's behalf with the King of Spain, especially concerning Catherine's unsatisfactory reaction to the spread of Calvinism within her realm and the rebellion of many her high-ranking Huguenot noblemen.

Though his reasons could possibly be attributed to his personal detestation of religious heresy, Philip's donation of military and financial aid in Spring 1562 to help suppress the Huguenot rebellions in the south of France is one of the first and most important examples of Élisabeth's role in the creation of a Spanish foreign policy program amendable to Catherine's interests. ${ }^{31}$ At the time of this offer, the Huguenots under the command of Louis I de Bourbon, prince of Condé had just entered the city of Orléans with 1,000-1,200 soldiers, fortifying the city as a base of operations against the armies of King Charles and the Queen Mother. ${ }^{32}$ After receiving notification of her son-in-law's offer, Catherine wrote to both Philip and her daughter

\footnotetext{
${ }^{31}$ Catherine de' Medici to Élisabeth de Valois, Queen of Spain, Lettres de Catherine de Médicis 1: 303.

${ }^{32}$ Nouvelle collection des mémoires pour servir à l'histoire de France depuis le XIII ${ }^{e}$ siècle jusqu'à la fin du XVIII' : François de Lorraine, le prince de Condé, Antoine du Puget, J. Fr. Michaud and Jean Joseph François Poujoulat (Paris, Chez l'éditeur du commentaire analytique du code civil, 1839). vol. 6: 628.
} 
expressing her gratitude to her son-in-law for his "bonne grase" and likewise telling Élisabeth to thank Philip for his intended aid to those who wish to do evil against Catherine and her government. ${ }^{33}$ Catherine would take Philip up on his offer, and the King of Spain would donate six thousand Spanish and Italian troops, as well as enough money to purchase the services of 4,000 German mercenaries, towards the eradication of religious heresy and to the maintenance of mother-in-law's regency. ${ }^{34}$ These Habsburg funded troops would subsequently participate on the side of the Royalist forces in the famous Catholic victory at Dreux in December 1562, where Condé would be captured and imprisoned "pour ces causes." 35

Of course, the contribution of soldiers and monies made by Philip to combat the threat of Calvinist rebellion cannot be entirely credited to the diplomatic maneuverings of Catherine and Élisabeth, since three years earlier, Henri II had solicited Philip's assistance against the Calvinist uprising in Bordeaux before Philip had met his bride. ${ }^{36}$ However, though Philip's affections for his French wife may have not been the genesis of Spanish intervention in the French Religious Wars, Élisabeth was still a vital component in the diplomatic discourse between the Spanish crown and Catherine's regency on how to solve their shared problem of the expansion of Protestantism. For instance, Élisabeth represented Philip in an interview with Catherine in Southern France in 1565 to "hammer out a common policy on extirpating heresy." 37 Élisabeth likewise served as a symbol of Franco-Spanish détente during the particularly unstable years of Charles IX's minority, even after her death in 1568. Though Élisabeth had been dead for nearly

\footnotetext{
${ }^{33}$ Catherine de' Medici to Philip II of Spain, LCM 1: 303, n. 1; Catherine de' Medici to Élisabeth de Valois, Queen of Spain, 9 May 1562, LCM 1:309.

${ }^{34}$ Pierre de Paschal, Journal de ce qui s'est passé en France durant l'année1562, principalement dans Paris et à la cour, ed. Michel François (Paris : 1950), 44.

${ }^{35}$ Nouvelle collection des mémoires 6: 693-5.

${ }^{36}$ Michele Suriano to the Doge of Venice, 3 December 1560, in Despatches of Michele Suriano and Marc' Antonio Barbaro, 1560-1563, ed. Sir Austen Henry Laylard (Lymington, UK: Huguenot Society of London, 1891), 10.

${ }^{37}$ Geoffrey Parker, The Grand Strategy of Philip II, (New Haven, CT and London: Yale University Press, 1998), 119.
} 
a year, Philip II would again send troops, this time numbering around four thousand, to aid his besieged former brother and mother-in-law in 1569, during the height of the Third Religious War. In the same year, Philip would likewise implore his relative Emperor Ferdinand I to do all in his power to prevent the entrance of additional German mercenaries into France on the side of the Huguenot rebels. ${ }^{38}$

However, the spread of heresy and the threat of Huguenot military insurgency was not the only domestic issue that Catherine sought partially to rectify through her daughter's relationship with the most formidable monarch in Europe. In a letter written to Élisabeth, dated March 22, 1561, Catherine indicated that she was being tormented by François de Lorraine, duke of Guise and his brother Charles, cardinal of Lorraine, who were spreading rumors both at court and abroad that questioned Catherine's commitment to Catholicism, accusing her of stealing the governance of the realm, and attempting to cast other such aspersions on Catherine's right to be regent. ${ }^{39}$ Catherine also indicated to her daughter that the Guise were trying to drive a wedge between Catherine and her easily manipulated ally, Antoine de Bourbon, informing him that ruling without the regent, and subsequently having all of France's resources at his full disposal, was "le seul moyen pour ravoyr la réconpanse de son royaume," "son royaume” being Spanishoccupied Navarre. Catherine then asked her daughter if she could persuade Philip II to return Spanish Navarre to Antoine de Bourbon, or at least offer him some form of compensation to conciliate him. ${ }^{40}$ Needless to say, Élisabeth was unable to convince her husband to cede a significant portion of Northern Spain to the king of Navarre to help alleviate his mother-in-law's political predicament.

\footnotetext{
${ }^{38}$ Catherine de' Medici to Raymond de Beccarie de Pavie, baron de Fourquevaux, 8 September 1569, LCM 3: 272.

${ }^{39}$ Catherine de' Medici to Élisabeth de Valois, Queen of Spain, 22 March 1561, LCM 1: 590-1; Catherine de' Medici to Élisabeth de Valois, Queen of Spain, April 1561, LCM 1: 592-3.

${ }^{40}$ Catherine de' Medici to Élisabeth de Valois, Queen of Spain, 22 March 1561, LCM 1: 590-1.
} 
Another means in which Catherine used her eldest daughter for the aggrandizement of the House of Valois, and subsequently her own political influence, was through brokering marriages between Catherine's remaining unmarried children and members of both the Spanish and Austrian branches of the House of Habsburg. From what we can tell from existing correspondence, a desired match between a young Charles IX and Philip II's younger sister Dona Juana, the widow of Juan Manuel, prince of Portugal, was the first marital alliance that Catherine solicited Élisabeth's assistance to achieve. In a letter written to the bishop of Limoges in May 1562, Catherine de' Medici explained to her ambassador at the Spanish court that she is depending on Élisabeth to "adviser d'enfourner et mectre en termes le dict marriage" to Philip, and Catherine charges Limoges with relating this information to the Queen of Spain since Catherine feared that Élisabeth's letters were being read before being given to her. For reasons of politesse, it is quite understandable that Catherine would be wary of this particular letter falling into the wrong hands. In addition to her more politically palatable reason for wanting this marriage, strengthening the nascent alliance between France and Spain, Catherine explained to Limoges that she would like to secure the marriage between Charles IX and Dona Juana as a safety measure in case Philip and Élisabeth remained childless and the Spanish Habsburg's possessions passed to Philip's sisters, Dona Maria, who would inherit Spain, and Dona Juana, who would receive the Spanish Netherlands and the Duchy of Milan. ${ }^{41}$ Though Catherine may have been considering this match for some time, this particular letter to Limoges was mostly likely in response to recent news that Don Carlos was suffering from yet another illness and that the death of Philip's heir was imminent. ${ }^{42}$

\footnotetext{
${ }^{41}$ Catherine de' Medici to Sebastien de l'Aubespine, bishop of Limoges, 18 May 1562, LCM 1: 318, 319 and n.1 .

${ }^{42}$ Limoges to Charles IX of France, 10 May 1562, LCM 1: 319 n. 1.
} 
The fact that Élisabeth had yet to conceive after nearly three years of marriage was not unusual since she was seventeen at the time that the letter was written, and Catherine adamantly stated to Limoges that she believed Élisabeth and Philip would have children eventually. ${ }^{43}$ However, regardless of Catherine's professed faith in Élisabeth's fecundity, this letter clearly shows that Catherine had alternative plans for Élisabeth's role in her political network if the queen of Spain failed in her primary duty: to win her husband's favor by producing a male heir, which would strengthen her position at the Spanish court, and to produce an heir that would be sympathetic to French interests strengthening amity between the French and Spanish kingdoms. If Élisabeth was able to assure the fruition of this marriage between Charles IX and Dona Juana, even if she remained childless, she would have been able to secure the acquisition of two economically lucrative and militarily beneficial territories for the French crown.

Though unsuccessful in her attempts at arranging a marriage between Charles IX and Dona Juana, Charles's desired Spanish bride would enter a convent, Élisabeth would once again be called upon by Catherine to help broker a marriage between Charles IX and another female member of the House of Habsburg. In a letter written to the queen of Spain, dated August 24, 1563, Catherine asked Élisabeth to inquire about her husband's “aupinion" of a potential marriage between Charles IX and Archduchess Elisabeth, the eldest daughter of the King of the Romans. In other words, Catherine was inquiring of her daughter whether or not the marriage between the Valois and the Austrian Habsburgs would negatively affect the relationship between the French and Spanish crowns. Catherine also wanted her daughter to relate to Philip II that the French crown would not want to enter an union that would run counter to the King of Spain's

\footnotetext{
${ }^{43}$ Catherine de' Medici to Limoges, May 1560, LCM 1: 318-19.
} 
will, and that her primary goal in brokering this marriage was to redouble France's Hapsburg alliances. ${ }^{44}$

Five years later, the subject of the Spanish Queen's intended involvement in the marriage negotiations for Charles IX with one of Elisabeth's sisters, the Archduchess Anne, appeared once again in Catherine's correspondence. ${ }^{45}$ In a letter written to Catherine from Raymond de Fourquevaux, Limoges's replacement at the Spanish court, Fourquevaux explained to Catherine that he had recently corresponded with the Spanish Queen, asking her to inform her husband that Fourquevaux would like to be received by Philip II at the monastery of Escurial, where Philip was temporarily residing, and to make sure that Fourquevaux found the King of Spain in good humor when he came to kiss hands and discuss the intended marriage alliance between the French crown and the Austrian Habsburgs. According to Fourquevaux, Queen Élisabeth wrote to Philip about the intended match, and though Fourquevaux did not say as much, it is implied that she had requested that Philip either help expedite the conclusion of the negotiations or make the Emperor more amendable to the match. Fourquevaux then received a letter from Philip, stating that the Emperor would soon send his brother, the Archduke Charles to France "exprez pour traicter le marriage." Fourquevaux then expresses to Catherine that the Archduke Charles's voyage to France is a good sign for the realization of her marriage ambitions for her son. ${ }^{46}$

However, despite Élisabeth's efforts, neither the marriage itself nor the negotiations would be completed during Élisabeth's lifetime. Catherine's correspondence from early 1569 indicates that the Holy Roman Emperor was still dragging his feet in regard to the marriage between Charles IX, and this time, his eldest daughter the Archduchess Elisabeth. It is interesting

\footnotetext{
${ }^{44}$ Catherine de' Medici to Élisabeth de Valois, Queen of Spain, 24 August 1563, LCM 10: 109.

${ }^{45}$ Catherine de' Medici to Fourquevaux, 13 June 1568, LCM 3: 148.

${ }^{46}$ Fourquevaux to Catherine de' Medici, 26 August 1568, LCM 3: 173-74 n. 4
} 
to note, however, that in these final letters concerning the conclusion of the marriage negotiations between the Valois and the Austrian Habsburgs, it is quite evident that Catherine is relying much less on her Spanish Habsburg connections to facilitate the match with the Austrian Hapsburgs. In a letter to Fourquevaux, dated January 1569, Catherine explained to her ambassador at the Spanish court that she is depending on the cardinal of Lorraine to conclude the marriage negotiations. ${ }^{47}$ Though it could be a possibility that Catherine, in relying or the cardinal of Lorraine after the death of Élisabeth, was trying to build a rapport with Austrian Habsburgs separate from Spain, it's much more likely that Catherine was much less able to call upon Philip II for favors since the physical embodiment of the union between France and Spain was now dead.

In addition to the aforementioned matches for Charles IX, Catherine also attempted to use her eldest daughter's relationship with the King of Spain to arrange an advantageous marriage for Catherine's youngest daughter, Marguerite, and to thwart the independent marriage ambitions of Mary Stuart, Queen of Scots that ran counter to Catherine's own foreign policy designs. Though her youngest daughter Marguerite was only seven at the time, Catherine initiated negotiations with Spain concerning marriage between Marguerite and Philip II's heir Don Carlos in 1560. The King of Spain had been married twice before his union with Élisabeth de Valois, and Don Carlos was a product of his first marriage to Maria Manuela, princess of Portugal. In a letter to the bishop of Limoges, Catherine requested that her ambassador tell the queen of Spain that she should try and find every opportunity to discuss this matter with Philip II, while carefully fostering her husband's favor. ${ }^{48}$ Other than Don Carlos's obvious physical and mental incapacities, and Marguerite's young age, Catherine believed that the greatest road block to the

\footnotetext{
${ }^{47}$ Catherine de' Medici to Fourquevaux, 20 January 1569, LCM 3: 221.

${ }^{48}$ Catherine de' Medici to Limoges, August 1560, LCM 1: 145-46.
} 
marriage between Marguerite and Don Carlos was Catherine's newly widowed former daughterin-law, Mary Stuart. Though ousted from power after the death of François II, the duke of Guise and his younger brother the cardinal of Lorraine now sought the aggrandizement of the house of Lorraine's fortune and influence through marriage between their niece the Queen of Scots and the heir to the Spanish throne.

By April 1561, it seems that Catherine had come to terms with the fact that Marguerite's age had disqualified her from being one of Don Carlos's potential brides. However, despite Élisabeth's inability to secure this match for her sister, Catherine still hoped that Élisabeth could thwart the Guise's similar aspirations for Mary Stuart. In a series of letters written to both the Spanish Queen and the bishop of Limoges in Spring 1561, the Queen mother related that the Guise brothers, evidently still reeling from their fall from power, had been undermining Catherine's regency. ${ }^{49}$ These missives seem to indicate that though Catherine was currently unable to nullify their political threat at home, the Queen mother wanted to ensure their house is not emboldened further through the marriage of their niece the queen of Scots to Don Carlos. Declaring that the failure of this marriage plot is necessary for the maintenance of her three her sons' personal securities, Catherine charged Limoges, in concert with Élisabeth, with the task doing "tout ce que vous sera possible pour romper ce coup."

In short, the fact that Catherine made these requests to her teenage daughter speaks volumes about Catherine's dependence on the goodwill of her son-in-law during the uncertain early years of her regency and how she likewise sought to obtain the support of her son-in-law through Philip II's affection for Élisabeth. Catherine's eldest daughter was "beautiful" and

\footnotetext{
${ }^{49}$ Catherine de' Medici to Élisabeth de Valois, Queen of Spain, April 1561, LCM 1: 592.

${ }^{50}$ Catherine de' Medici to Limoges, 1 April 1561, LCM 1: 595 and n. 2.
} 
"agreeable" "honored and respected" and there was every indication that Philip adored her. ${ }^{51}$

Catherine understood her precarious position as regent, and she knew that the support of her sonin-law Philip was crucial to legitimating and prolonging her regency, as well as to ensuring the political security of the House of Valois. Though she was not always successful in using Philip's affection for her daughter Élisabeth for her own political gain, Catherine was able to build a comparatively healthy Franco-Spanish alliance that endured even after her daughter's death in 1568, which proved beneficial to both the maintenance of the realm and to the consolidation of her own political influence.

\section{Marguerite de Valois: Queen of France and Navarre}

Known popularly to posterity as "La Reine Margot," Marguerite de Valois was born on May 14, 1553 in the château de Saint-Germaine-en-Laye, making her seven years younger than her sister Élisabeth. ${ }^{52}$ Her contemporary, the abbé de Brantôme, described Marguerite as possessing a "beautiful face" resting on a "beautiful, superb, and rich" body, making her resemble "a goddess of heaven" as opposed to a "princess of earth."53 Although Marguerite's undeniable good looks were eventually tainted by her numerous sexual indiscretions and poor judgment, Catherine de' Medici initially had high hopes for the marriage prospects of her youngest and most attractive daughter, and it is easy to see why. In addition to her handsome features, the young Marguerite was not particularly intelligent or ambitious, and made every

\footnotetext{
${ }^{51}$ Brantôme, Illustrious Dames, 47, 45.

${ }^{52}$ Éliane Viennot, Marguerite de Valois: Histoire d'une femme, histoire d'un mythe. (Paris: Grande Bibliothèque Payot, 1995): 22.

${ }^{53}$ Brantôme, Illustrious Dames, 153.
} 
attempt to please her domineering mother, rendering Marguerite in every respect a pliable tool for Catherine's own political gain. ${ }^{54}$

As with her daughter Élisabeth, Catherine initially conceptualized Marguerite's primary function within her political network in the usual way that a monarch would seeks to utilize a daughter for political gain: as a means of securing a valuable foreign alliance. While Catherine's plans to use Marguerite to consolidate her powerbase abroad would eventually be left unrealized, renewed tensions between Catholics and Protestants following Marguerite's marriage to Henri de Bourbon, king of Navarre left Marguerite with a new purpose in her mother's network. The subsequent St. Bartholomew's Day Massacre (August 1572) left Marguerite with a new purpose within Catherine's network: to control and assuage domestic crises. Though it is the general consensus among historians that Marguerite, during her tempestuous marriage with the King of Navarre, was more of a headache to Catherine than a valuable ally, evidence shows that, despite their frequent personal and political disagreements, Catherine used Marguerite both to cultivate a more amicable relationship with the king of Navarre, Marguerite's spouse and the leader of France's Huguenot population, and to help build a lasting peace between the warring Catholic and Huguenot parties.

As previously mentioned, Catherine's first ambition for her daughter Marguerite was to marry her to Don Carlos, prince of Asturias, heir to the king of Spain. Despite his "degenerate" and "sadistic" nature, as well as his "severe epilepsy," Don Carlos was the most eligible bachelor in Christendom and marriage between Marguerite and the Spanish prince would ensure the

\footnotetext{
${ }^{54}$ Viennot, Marguerite de Valois, 23; Marguerite de Valois, Memoirs of Marguerite de Valois, Queen of France, Wife of Henri IV of Madame de Pompadour of the Court of Louis XV and of Catherine de Medici, Queen of France, Wife of Henri II, ed. Marguerite du Hausett (New York, NY: P.F. Collier \& Son, 1910), 25.
} 
continuation of the Franco-Spanish alliance after the death of King Philip. ${ }^{55}$ However, there were numerous obstacles to this match, the first being competition from other female royals, most notably Catherine's former daughter-in-law Mary, Queen of Scots, the second being Marguerite's age, and the third and most important being Don Carlos's mental instability which subsequently led to his confinement and death. ${ }^{56}$

Regardless, the subject of Marguerite's marriage to a member of the Spanish royal house reemerged when her sister Élisabeth died in 1568 due to complications in childbirth. Though Catherine's letters to the new French ambassador to Spain, Raymond de Fourquevaux, indicate that she was indeed saddened by the "malheureuse nouvelle" of the death of Élisabeth, Catherine lost no time filling the hole in her diplomatic network left by her eldest daughter. ${ }^{57} \mathrm{~A}$ little over a month after Élisabeth's death, Catherine offered Marguerite as a replacement bride for Philip II because she desired to preserve "la paix entre les deux roys." ${ }^{58}$ However, Philip tastefully declined this offer and Catherine then turned her attention to the possibility of match between Marguerite and King Sebastian I of Portugal, with King Philip, who had apparently first proposed the match, acting as a mediator in the marriage negotiations ${ }^{59}$ With Catherine's former son-in-law Philip acting as the match's primary broker, the marriage between Marguerite and the king of Portugal seemed to be a fait accompli, and Catherine even went so far as officially announcing their engagement to her cousin Cosimo de' Medici, Duke of Florence, and to Queen Elizabeth I of England in August $1569 .{ }^{60}$ Despite Catherine's expressed fear that Marguerite's temperament would foil the marriage arrangements, it seems that it was her former son-in-law

\footnotetext{
${ }^{55}$ Alison Weir, Mary, Queen of Scots and the Murder of Lord Darnley (New York, NY: Ballatine Books, 2009), 40.

${ }^{56}$ Catherine de' Medici to Bernardin Bochetel, bishop of Rennes, 20 October 1563, LCM 2: 106.

${ }^{57}$ Catherine de' Medici to Fourquevaux, LCM 3: 198.

${ }^{58}$ Catherine de' Medici to Fourquevaux, LCM 3: 206.

${ }^{59}$ Fourquevaux to Catherine de' Medici, January 1569, LCM 3: 221-22 n. 2.

${ }^{60}$ Catherine de' Medici to Cosimo de' Medici, Duke of Florence, 11 August 1569, LCM 3: 267; Catherine de' Medici to Queen Elizabeth I of England, 15 August 1569, LCM 3: 267.
} 
who would in fact frustrate Catherine's marriage ambitions for Marguerite. Now married to Anne of Austria, the Holy Roman Emperor's second eldest daughter, Philip began to stall the marriage negotiations in the summer and autumn of 1570, causing Catherine, his concerned former mother-in-law, to write numerous letters both to Philip and to her ambassador at the Spanish court to do all in their power to finalize the terms of the marriage ${ }^{61}$ However, regardless of Catherine's diplomatic implorations to her former son-in-law, the king of Spain thwarted Marguerite's marriage to Sebastian because, in Marguerite's opinion, Philip did not want his nephew, the king of Portugal, to marry outside of Philip's family. ${ }^{62}$ Due to the childlessness of both Sebastian and his brother, Philip would become the king of Portugal, and as such, the first king in several centuries to rule over the entire Iberian Peninsula. ${ }^{63}$

It was shortly after the failed negotiations with the Portuguese King that Catherine earnestly considered marrying Marguerite to Marguerite's cousin Henri de Bourbon, son of Antoine de Bourbon and Jeanne d'Albret, the king and queen of Navarre. According to Marguerite's memoirs, it was the more politique Montmorency clan who first broached this subject with the Queen Mother before the Third Religious War and the subsequent Treaty of Saint-Germain-en-Laye had been concluded in $1570 .{ }^{64}$ However, the correspondence of Antoine de Bourbon and Ippolito II d'Este, cardinal of Ferrara respectively seem to indicate otherwise. From a letter written to his aunt and Guise family matriarch, Antoinette de Bourbon, the dowager duchesse de Guise, we know that the Jing of Navarre had offered his son and heir, Henri de Bourbon as a potential groom for "Madame Marguerite" as early as 1559 , and from the correspondence of the cardinal of Ferrara to Pope Pius IV, we know that Catherine publicly

${ }^{61}$ Catherine de' Medici to Philip II of Spain, 12 August 1570, LCM 3: 327; Catherine de' Medici to Philip II of Spain, 13 August 1570, LCM 3: 328; Catherine de' Medici to Fourquevaux, 14 August 1570, LCM 3: 329.

${ }^{62}$ Marguerite de Valois, Memoirs, 32.

${ }^{63}$ Parker, The Grand Strategy of Philip II, 86-7.

${ }^{64}$ Ibid., 33. 
discussed this possibility with the king of Navarre after Don Carlos seriously injured himself falling down a flight of stairs in $1562 .{ }^{65}$ Given that Marguerite still had better marriage options for much of the 1560s, in addition to Don Carlos and the king of Portugal, Archduke Rudolph of Austria (later Emperor Rudolph II) was also considered, and that the proposed bridegroom was being currently raised by the staunchly Calvinist Jeanne d'Albret miles away from the Valois court, it is unlikely that Catherine de' Medici was serious in her proposal to the king of Navarre. ${ }^{66}$ Her suggestion of a potential marriage between Marguerite and Henri de Bourbon was more likely a means of keeping the politically inconsistent, though decidedly influential king of Navarre in line with her interests. In fact, the Guise brothers used a similar tactic two years earlier, promising the credulous Antoine de Bourbon marriage with the Queen of Scots if he supported the house of Lorraine in their endeavors. ${ }^{67}$

Yet, with the treaty of Saint-Germain-en-Laye (1570), the crown was now at peace with France's Huguenots, and a marriage between her daughter and the future king of Navarre was deemed a good conciliatory gesture towards "yesterday's enemies." 68 Though the Calvinist Jeanne d'Albert was initially opposed to the marriage and a dispensation had to be sought, due to both the consanguinity of the couple and the faith of the bridegroom, Catherine was a great proponent of the marriage and personally petitioned Pope Gregory XIII for the dispensation. ${ }^{69}$ In addition to the obvious domestic benefits of the match, to assuage the religious conflict with the

\footnotetext{
${ }^{65}$ Antoine de Bourbon, King of Navarre to Antoinette de Bourbon, Dowager Duchess of Guise, 1559 in La Mère des Guises: Antoinette de Bourbon, 1494-1583, ed, Gabriel de Pimodan (Paris: Edouard Champion, 1925), 350; Ippolito II d'Este to Pope Pius IV, quoted in Journal de l'Année 1562, 44. This potential union was also discussed in Perrenot de Chantonnay to the Duchess of Parma, 16 January 1561, LCM 1: 576 n.3.

${ }^{66}$ Catherine de' Medici to Rennes, 13 October 1564, LCM 2: 230.

${ }^{67}$ Nancy Lyman Roelker, Queen of Navarre: Jeanne d'Albret, 1528-1572 (Cambridge, MA: Belknap Press of Harvard University Press, 1968), 181.

${ }^{68}$ Frieda, Catherine de Medici, 225.

${ }^{69}$ Catherine de' Medici to François de Rougier, Baron of Ferals, October 1571, LCM 4: 75; Catherine de' Medici to Pope Gregory XIII, 13 July 1572, LCM 4: 106-7; Catherine de' Medici to Pope Gregory XIII, 19 August 1572, LCM 4: 110 .
} 
realm, Catherine's letters also indicate that Catherine hoped that this marriage between Marguerite and the Huguenot Henri de Bourbon would please other Protestant powers. For instance, while relating the news of Marguerite's and Henri de Bourbon's impending marriage in letter to the English Queen Elizabeth, Catherine tells her "très chère et très aimée bonne sœur et cousine" that Catherine is certain that the English Queen is hearing this news with great pleasure. ${ }^{70}$ In addition to the obvious pleasure that the Protestant queen of England would take in learning of this conciliatory gesture between the French crown and its Huguenots, Catherine may have hoped that the betrothal of Marguerite to Henri de Bourbon would encourage the possibility of another marriage between the house of Valois and another Protestant state, namely a union between Queen Elizabeth I of England and the duke of Alençon.

The wedding of Marguerite de Valois and Henri de Bourbon, now king of Navarre, took place in Paris on August 18, 1572, and what happened next is well known. It is not the objective of this thesis to determine Catherine de' Medici's role in the St. Bartholomew's Day Massacre, but its mention is essential to explain the evolving role of Marguerite within Catherine's female political network. With her new son-in-law confined in Paris, his political and religious threat nullified, Catherine asked Marguerite if she was desirous for the dissolution of her marriage to Henri de Bourbon. Marguerite declined this offer, Catherine surprisingly conceded to her request, and Marguerite remained married to Henri de Bourbon until after Catherine's death. ${ }^{71}$

If Catherine de' Medici had hoped that with the continuation of her daughter's marriage to Henri de Bourbon she would be able to use Marguerite to track the political movements of Henri de Bourbon, she was initially right in her assumptions. When the royal court accompanied

\footnotetext{
${ }^{70}$ Catherine de' Medici to Elizabeth I of England, 22 April 1572, LCM 4: 97-98.

${ }^{71}$ Marguerite de Valois, Memoirs, 42.
} 
Henri de Valois, duke of Anjou and king-elect of Poland, to Beaune to wish him farewell before departing for his new kingdom, Marguerite's husband and youngest brother, the perpetually malcontent François de Valois, duke of Alençon, made plans to break away from the royal entourage and connect with Huguenot troops on their return to Paris. Upon hearing of these preparations, Marguerite dutifully informed King Charles and Catherine of her husband's and brother's schemes, and the two men were prevented from joining the Huguenots. ${ }^{72}$

Of course, Marguerite would not always be so keen to offer information concerning Navarre and Alençon to her mother, and Marguerite's conduct would not always be so politically beneficial to Catherine. In September 1575, the duke of Alençon and the king of Navarre were finally successful in their attempts to escape from the Valois court, and rather than inform her mother and King Henri III of their intentions (King Charles had since died) Marguerite concealed their plans for departure. ${ }^{73}$ In her memoirs, Marguerite describes how Alençon waited until dusk, and covering the lower half of his face, walked on foot to the gate St. Honore where he was met a coach that took him out of Paris. When asked by her mother and brother, King Henri III why Alençon has not supped with them that evening, Marguerite feigned ignorance for the reason of his absence. ${ }^{74}$ Needless to say, Catherine would eventually become aware of Marguerite's complicity in both Navarre's and Alençon's respective escapes. After writing a rather long letter to her son, King Henri III, on Alençon's flight, Catherine adds the ominous post-script "Je ayscrips a vostre seur, afin d'aduisir le marche."

Despite Marguerite's previous dissimulation in regards to the escape of her husband and brother, Catherine de' Medici was nonetheless quite desirous to have her daughter reunited with

\footnotetext{
${ }^{72}$ Ibid., 44-5.

${ }^{73}$ Catherine de' Medici to Emmanuel Philibert, Duke of Savoy, 15 September 1575, LCM 5: 132.

${ }^{74}$ Marguerite de Valois, Memoirs, 68.

${ }^{75}$ Catherine de' Medici to Henri III of France, 23 September 1575, LCM 10: 49.
} 
the king of Navarre at his court at Nérac, most likely since Marguerite's position as queen of Navarre was obviously of very little use to her mother when separated from her husband. ${ }^{76}$ Therefore, with Catherine accompanying her, Marguerite made her way to southern France where she reunited with her husband at Castéras in September 1578. With the king and queen of Navarre finally reunited, Catherine lost no time in using the relationship between her daughter and the leader of the Huguenot party to benefit her and the realm. In a letter to Henri III recounting the happenings of the gathering at Castéras, Catherine explains to her favorite son that she used this meeting to impress upon the king of Navarre the French crown's desire for peace with its Huguenot subjects and likewise to express Henri III's perfect love for his Bourbon cousin, whom he viewed as his true heir after the duke of Alençon. ${ }^{77}$ It seems that while Catherine was conveying her son's newfound amity for the king of Navarre, Marguerite was likewise doing her part to facilitate peace between Henri III and France's Huguenot population, by primarily echoing the sentiments already made by her mother to her husband. ${ }^{78}$ As one of his former captors, Catherine probably realized that the king of Navarre would be reluctant to trust the Queen mother and her overtures of peace, therefore, Catherine more than likely solicited Marguerite to act as Catherine's advocate in these matters, since as both his wife and ally during his confinement at the Valois court, Navarre would have been more inclined to listen to Marguerite.

Two months following Marguerite's and Henri’s reunion at Castéras, Catherine accompanied her daughter to Henri de Bourbon's court at Nérac where preparations were underway for a conference between Protestant leaders and the French crown, with Catherine

\footnotetext{
${ }^{76}$ Catherine de' Medici to Pomponne de Bellièvre, 12 May 1578, LCM 6: 26.

${ }^{77}$ Catherine de' Medici to Henri III of France, 2 October 1578, LCM 6: 46-47.

${ }^{78}$ Catherine de' Medici to Henri III of France, 4-5 October 1578, LCM 6: 50.
} 
acting on Henri III's behalf. ${ }^{79}$ The presence of Catherine's attractive ladies-in-waiting would eventually cause a slight rift between Navarre and Marguerite. Still, the king and queen of Navarre seemed to be on good terms throughout the duration of the conference, and Catherine was predictably pleased with their amicable reunion, since it allowed Catherine to influence her son-in-law through his amity with Marguerite. One of the first issues that Catherine sought to manipulate through the intervention of Marguerite was the location of the conference itself. With her husband apparently suffering from a migraine, Marguerite departed from the Port-SaincteMarye, where she and Catherine were residing, for Nérac, where the king of Navarre was supposed to be convalescing. Though Marguerite apparently found her husband in good health, Catherine told her daughter that she should remonstrate with the king of Navarre for choosing Nérac as the conference site, since its position between both a high mountain and a river rendered those residing there more susceptible to ailments. Catherine then enlisted Marguerite to persuade the king of Navarre to move the conference to Villeneuve. ${ }^{80}$ Despite Catherine's assertions over her son-in-law's health, it is more likely that she was reluctant enter the rabidly Protestant Nérac, fearing imprisonment by the king of Navarre once she had entered the city, or Huguenot reprisals taken against her for the St. Bartholomew's Day massacre.

Despite Marguerite's evident failure to move the location of the conference to Villeneuve, Marguerite would still play an important diplomatic and symbolic role in the course of the conference, as well as in the maintenance of peace in the years following the conference at Nérac. In a letter written to Marguerite, dated August 1579, Catherine implores Marguerite to not lose the "courage et fault que usiez de l'auctorité de ce que vous estes et que vous envoiez quelqu'un catholique." She reminds her daughter that she is the Catholic sister of the king of

\footnotetext{
${ }^{79}$ Catherine de' Medici to Henri III of France, 16 December 1578, LCM 6: 173.

${ }^{80}$ Catherine de' Medici to Henri III of France, 4 January 1579, LCM 6: 200.
} 
France, and as such, she must actively desire and seek the conservation of all good Catholic subjects within the kingdom. Therefore, Catherine entreats her daughter to do all in her power to preserve the tenuous peace established at Nérac, which is beginning to unravel. Catherine then indicates to Marguerite that a more permanent peace may be secured if the king of Navarre agreed to visit Henri III, assuring her daughter that if Henri de Bourbon paid a visit to the Valois court, he would be received like a true officer of the crown and servant of the king. However, if the war recommences, it will be to no one's benefit except for France's “ennemis," meaning mostly likely the Spanish. ${ }^{81}$

In an attempt to build a more lasting peace between the French King Henri III and the king of Navarre, Catherine likewise enlisted Marguerite's help in severing the relationship between the king of Navarre and his hotheaded and rabidly Calvinist cousin Henri de Bourbon, prince de Condé. In a letter to Henriette de Clèves, Duchess of Nevers, Catherine indicates that she had been recently told that the prince of Condé, who was much less willing to compromise with the Valois, had sought out the king of Navarre. Though Catherine does not specifically state what her suspicions are of why this meeting occurred, Catherine nonetheless relates to the duchess of Nevers that she has written to Marguerite asking her break up the two Bourbon cousins. ${ }^{82}$ It is impossible, of course, to measure what affect, if any, Marguerite had on the relationship between her husband the king of Navarre and the prince de Condé, it seems that Catherine was, at least until 1582, pleased with Marguerite's conduct as Queen of Navarre, as well as Marguerite's efforts on behalf of the French crown. ${ }^{83}$

\footnotetext{
${ }^{81}$ Catherine de' Medici to Marguerite de Valois, Queen of Navarre, 28 August 1579, LCM 10: 447-8.

${ }^{82}$ Catherine de' Medici to Henriette de Clèves, Duchess of Nevers, 29 November 1580, LCM 7: $296-97$.

${ }^{83}$ Catherine de' Medici to Nicolas de Neufville, seigneur de Villeroy, 12 January 1581, LCM 7: 319.
} 
Despite the evident trust that Catherine placed in Marguerite, Catherine's ambitions for her youngest daughter would be soon disappointed. Due to political and religious disagreements, as well as infidelities on both sides, Marguerite and her husband were frequently at odds around two years after their reunion. As a result, after an embarrassing false pregnancy in late 1581, Marguerite took the opportunity to rejoin her mother at the Valois court. ${ }^{84}$ Upon her return to Paris, Marguerite's behavior became increasingly erratic and morally dissolute. In addition to publicly insulting King Henri III and openly keeping lovers, Marguerite was suspected by Catherine of attempting to turn Catherine's youngest son, François, now duc d'Anjou, against Henri III. ${ }^{85}$ Though her husband was little inclined to have Marguerite returned to him, Marguerite was ousted from her brother's court in Paris in 1583, and with some political scolding from Catherine and King Henri III, the king of Navarre allowed Marguerite to return to him at Nérac. ${ }^{86}$ Neglected by the king of Navarre and rendered politically insignificant, Marguerite would leave her husband's court in Nérac for Agen, where she established a government and made preparations for the fortification of the city with the aid of "beaucoup de jans dhonneur," much to annoyance of husband, brother and mother ${ }^{87}$ Despite Marguerite's seemingly inexcusable behavior, Catherine nonetheless wrote numerous letters to Marguerite, counseling her to make better decisions, while still seeking to reconcile her rebellious daughter with her philandering husband. However, by 1586, it was evident to both Catherine and Henri III that Marguerite's behavior had rendered her reputation and political use beyond saving, and Marguerite was imprisoned by her brother in the château d'Usson, where she remained until the succession of her husband Henri IV (1589-1610) to the French throne.

\footnotetext{
${ }^{84}$ Catherine de' Medici to Bellièvre, 27 December 1581, LCM 7: 420.

${ }^{85}$ Catherine de' Medici to Bellièvre, 31 July 1583, LCM 8: 116-7.

${ }^{86}$ Catherine de' Medici to Bellièvre, 26 January 1584, LCM 8: 172.

${ }^{87}$ Catherine de' Medici to Jean de Monluc, sieur de Balagny, 9 January 1585, LCM 8: 300; Marguerite de Valois, Correspondance: 1569-1614, ed. Eliane Viennot (Paris: Honoré Champion Editeur, 1998), 322.
} 
Yet, despite these efforts on her mother's behalf, it is the general belief among historians that Marguerite de Valois was of more of a headache and an ally to her mother. Of course, Marguerite did continually provide Catherine de' Medici with so many "nouveaux ennuix" during Catherine's lifetime. However, it is important to remember that Catherine never gave up hope that Marguerite, as Queen of Navarre, would act in a capacity that was beneficial to the designs of both Catherine and her favorite son Henri III, and as a result, at least for a few years, Catherine's patience with Marguerite did prove beneficial to Catherine's political agenda ${ }^{88}$ In addition to the conferences at Nérac, where Catherine was able to establish some semblance of accord between Huguenot nobles led by the Kkng of Navarre and the French crown, Catherine's letters indicate that the Catholic Marguerite served as a symbol for the potential of "paix" between the warring and Huguenot and Catholic parties. ${ }^{89}$ During her first years at her husband's court, Marguerite likewise served as an intermediary between her mother and brother and the king of Navarre.

As indicated by this chapter, Catherine's eldest and youngest daughters possessed an important place within Catherine's domestic and foreign policy designs. In addition to acting as both her advocate and apologist at the Spanish court, Catherine enlisted her daughter Élisabeth to help secure the dynastic legacy of the house of Valois by helping to obtain advantageous marriages for her siblings. In the case of Marguerite, Catherine primarily hoped that her youngest daughter would assuage relations with the French Huguenot population. Though both Marguerite's poor choices and bouts of rebelliousness certainly caused Catherine many political headaches in the last decades of her life, Marguerite did in some instances prove useful to

\footnotetext{
${ }^{88}$ Catherine de' Medici to Balagny, 9 January 1585, LCM 8: 300.

${ }^{89}$ Catherine de Medici to Henri III of France 6 February 1579, LCM 6: 252; Catherine de Medici to Henri III of France, 8 and 9 February 1579, LCM 6: 254.
} 
Catherine political designs. In short, Catherine astutely realized her daughters had the potential to be an important piece in the game of both international and domestic politics, and as a result of her creation of this female kinship-based political system, she was often able to make substantial gains in the way of both domestic and foreign politics. 


\section{Chapter 2: Catherine's daughters-in-law}

Like her daughters Élisabeth and Marguerite, Catherine also sought to incorporate other potentially influential female relatives, most notably her daughters-in-law, Mary Stuart, Queen of Scots, Elisabeth of Austria, and Louise of Lorraine-Vaudémont, into her political network for the purposes of simultaneously solidifying foreign alliances and moderating domestic politics. However, also similar to the cases of the queens of Spain and Navarre, Catherine's attempts to capitalize on her relationship with her daughters-in-law often produced inconsistent or unsuccessful results. As shown in the previous chapter, Catherine's daughters Élisabeth and Marguerite possessed a distinguishable role within Catherine's network, and frequently, their position within that network was a great benefit to the Queen mother. Though they had married into other royal houses, it is evident from Catherine's letters that, as both Catherine's daughters and the sisters of the king of France, Élisabeth and Marguerite were expected by the Queen mother to represent the interests of France and the House of Valois in their interactions with their royal spouses, even if those interests may have been incongruous with the policies previously embraced by their husband's respective governments.

One would assume that the high pedigree of Catherine's daughters-in-law, as well as the political influence of their families, would have allowed Mary Stuart, Elisabeth of Austria, and to a lesser extent Louise de Lorraine-Vaudémont, to assume a diplomatic function similar to those adopted by Catherine's daughters. Of course, there were additional factors that prevented these French consorts from establishing a strong political footing at the Valois court, however, it was their simultaneous existence within two or more political networks, particularly in the case of Mary Stuart and Louise de Lorraine-Vaudémont, that prevented Catherine from effectively utilizing her daughters-in-laws to the extent that she did the queens of Spain and Navarre. Since 
one of this chapter's main purposes is to study how the overlap of family-oriented political networks may have inhibited the diplomatic effectiveness of Mary Stuart, Elisabeth of Austria and Louise de Lorraine-Vaudémont for Catherine's political designs, this section on Catherine's daughters-in-law will be less of a study on how members of Catherine's network impacted sixteenth-century French politics. Instead, it will mainly provide a case study on how Catherine sought and failed to incorporate influential women within her political system.

\section{Mary Stuart, Queen of Scots}

The only surviving child of James V of Scotland and his French consort Marie de Guise, Mary Stuart was born December 8, 1542 and succeeded to the throne six days later with the death of her father after a disastrous defeat of the Scottish army at Solway Moss. ${ }^{90}$ Following the death of King James, Mary's cousin and heir, James Hamilton, earl of Arran assumed control of the governance of the realm. Threatened by the entrance of additional English soldiers across the southern border, Arran began negotiations with Henri II for the marriage of the young Queen of Scots to Henri II's and Catherine de' Medici's eldest son, the dauphin François, with the understanding that the French king would send French troops to help expel the English from the Scottish kingdom. Once the dispatched French army had finally recaptured some militarily strategic towns from the English, the marriage contract was ratified, and the young Scottish Queen was sent to the French court in 1548 to be raised with her future husband, as her mother, Marie de Guise, wrestled away the reins of power in Scotland from the Earl of Arran. ${ }^{91}$

At the French court, Mary Stuart was raised alongside Catherine's daughters, and like the three Valois princesses, her education was monitored by Henri II's maitresse en titre Diane de

\footnotetext{
${ }^{90}$ A. Cheruel, Marie Stuart et Catherine de Médicis (Paris: Hachette, 1858), 10.

${ }^{91}$ Weir, Mary Queen of Scots, 11; ibid., 13-6.
} 
Poitiers. ${ }^{92}$ It would be another decade before the young Queen of Scots would marry the dauphin, and though their marriage would be cut short by François's ill-health, the two evidently spent their short union "in great love and pleasant concord." ${ }^{, 3}$ However, despite the tender affection that her son François was supposed to have borne towards his Scottish wife, Catherine's personal and political dislike of Mary Stuart was well known both in France and in foreign courts, culminating in Mary's rather unceremonious ejection from France by Catherine two years after the death of François II. Though political necessity would require the reestablishment of cordial diplomatic relations between the two women, this latent animosity which found its naissance during Mary's adolescence in France would unfavorably taint Catherine's relationship with the Queen of Scots for the duration of Mary's reign.

So, how did the relationship between Catherine and her teenage daughter-in-law deteriorate to the extent that Catherine would allow her personal sentiments potentially to jeopardize her government's rapport with the Scottish Queen, who, in addition to ruling over France's longest ally, also had a strong chance of succeeding to the throne of England? First, Mary's own temperament and arrogance played a significant role in Catherine's ire. While Henri II was still alive, and Catherine subordinate to her husband's mistress, Mary probably learned to view Catherine with condescension, due to both Catherine's comparatively common lineage and unimportant status at the Valois court, from Diane de Poitiers herself. ${ }^{94}$ In that vein, Mary was supposed to have famously remarked to the Queen mother, during the reign of François II, that

\footnotetext{
${ }^{92}$ Weir, Mary Queen of Scots, 12-3.

${ }^{93}$ Brantôme, Illustrious Dames, 93.

${ }^{94}$ Weir, Mary Queen of Scots, 13.
} 
Catherine would "never be anything but a merchant's daughter," though this comment may have come about more at the suggestion of the cardinal of Lorraine as opposed to Diane de Poitiers. ${ }^{95}$ Yet, despite any personal resentment that may have arisen from these slights, Catherine did possess some legitimate political justifications for her treatment of Mary after the death of François II. In addition to the authority and prestige accompanying her position as Queen of Scots, Mary Stuart, through her mother, was a key member of one of the most economically dominant and politically influential noble dynasties to emerge in Europe during the early modern period, the cadet branch of the house of Lorraine, the house of Guise. Since the founding of the house of Guise in France during the mid-1520s, the duke of Guise and his male relatives had become some of the greatest landed magnates in the realm, with powerbases in Normandy, Picardy, and Champagne and had established an "ecclesiastical empire" of sorts, with the house's younger sons acting as some of the kingdom's most prominent and richest prelates. ${ }^{96}$ More importantly however, the duke of Guise and his younger brother the cardinal of Lorraine, were among the most political influential men at court at the time of Henri II's death in 1559, with their extensive clientage network slowly undermining the position of influential Montmorency and Bourbon clans. Though Guise historian Stuart Carroll has recently asserted that the Queen mother and the Guise brothers initially had a cordial and symbiotic relationship, because the Guise "accorded Catherine with the respect she craved" while Diane de Poitiers was still a fixture at court, a salient rivalry had formed between the Guise and the Queen mother by the end of François II's reign. ${ }^{97}$ Upon François II's accession to the throne, the Guise brothers

\footnotetext{
${ }^{95}$ Monsignor Santa Croce to Cardinal Borromeo, 27 June 1563, in Papal Negotiations with Mary Queen of Scots During her Reign in Scotland: 1561-1567, ed. John Hungerford Pollen, S.J. (Edinburgh, Printed at the University Press by T. and A. Constable, for the Scottish History Society, 1901), 449.

${ }^{96}$ Stuart Carroll, Noble Powers during the French Wars of Religion: The Guise Affinity and the Catholic Cause in Normandy (Cambridge: Cambridge University Press, 1998), 33.

${ }^{97}$ Stuart Caroll, Martyrs and Murders: The Guise Family and the Making of Europe (Oxford, Oxford University Press, 2009), 101.
} 
were partially able to assume many governmental powers, and thwart Catherine's own ambitions, on the pretext that they were related to François II's consort. When François II died, the Guise likewise used the widowed Mary Stuart to control Catherine's sometime ally Antoine de Bourbon, promising a handsome young wife and a new kingdom to the gullible middle-aged lieutenant general. ${ }^{98}$

Another cause of the antagonism between Catherine and Mary appears to have been Mary's marriage prospects to Don Carlos, son of Philip II and heir to the Spanish crown, since as stated earlier in this essay, Catherine de' Medici's great ambition was to marry her daughter Marguerite to Don Carlos. ${ }^{99}$ Despite Guise's admission in January 1561 that the King of Spain was probably not willing to betroth Don Carlos to the Queen of Scots, due to Philip's heir's illhealth, Catherine's frantic letters to Queen Élisabeth and the bishop of Limoges in the spring and summer of that same year indicate that Catherine not only believed that Marguerite was still a contender for Don Carlos's hand, but also that Mary Stuart would still be viewed as an advantageous alternative to the French princess. ${ }^{100}$ Mary's uncle, the cardinal of Lorraine, had at one time spoken to Catherine about arranging a betrothal between the Queen of Scots and the Austrian Archduke Charles. ${ }^{101}$ Therefore, with the intention of directing Mary away from the Spanish prize, Catherine tried to encourage a marriage between Mary and youngest son of Ferdinand I, Holy Roman Emperor in April $1561 .{ }^{102}$ However, as previously indicated, the Queen of Scots would marry neither Don Carlos nor the Archduke Charles. Mary was induced by Catherine to leave the French court for her native Scotland in August 1561, leaving behind

\footnotetext{
${ }^{98}$ Roelker, Queen of Navarre, 181; Jeanne d'Albret, Jeanne d'Albret: Mémoires et Poésies. (Geneva : Slatkine Reprints, 1970), 3.

${ }^{99}$ Catherine de' Medici to Limoges, August 1560, LCM 1: 145.

${ }^{100}$ M. Commendone to Cardinal Borromeo, January 1561, Papal Negotiations, 87; Catherine de' Medici to Limoges, 21 April 1561, LCM 1: 190; Catherine de' Medici to Élisabeth de Valois, Queen of Spain, August 1561, LCM 1: 605.

${ }^{101}$ Paul Van Dyke, Catherine de Médicis (New York, NY: Charles Scribner's Sons, 1922), 295.

${ }^{102}$ Catherine de' Medici to Rennes, 11 April 1561, LCM 1: 186
} 
her lucrative possessions in France while being refused assurances of safe passage from Elizabeth I of England. ${ }^{103}$

However, it seems that once Mary had established herself in Edinburgh, and had been physically distanced from her ambitious Guise relatives, Catherine was more inclined to reestablish a friendly rapport with her former daughter-in-law, who was now a reigning head of state. Though the threat to Marguerite's marriage to Don Carlos had not been entirely removed, Catherine made concentrated steps at rebuilding her relationship with the Queen of Scots almost immediately after Mary return to Scotland. In late December 1562, Thomas Randolph, the English ambassador the Scottish court, notes in his correspondence to Secretary of State William Cecil that the Mary had received letters from Catherine "“with moe gentle words then ever she dyd wryte before."' Aware of previous animosity existing between the Queen mother and the Queen of Scots before Mary's departure, Randolph could only surmise that Catherine was now attempting to "courriethe favour" "with her former daughter-in-law. ${ }^{104}$

Less than a year later, in one of his reports to Cecil, Randolph relates the contents of another letter written to the Queen of Scots by the Queen mother. According to Randolph, Catherine, with this letter, related news on the present "discords" within France, and likewise implored her daughter-in-law to remember the "'frendeshippe and olde alliance betwene the two realms she is bound," in an obvious reference to the centuries-old Auld Alliance. The Queen of Scots was apparently unmoved by her mother-in-law's manifestations of friendship, commenting to the English ambassador that she did not know how "this new kindness came about," and that as far as Mary was concerned, the friendship of queen of England "may stand her more in her

\footnotetext{
${ }^{103}$ Weir, Mary, Queen of Scots, 25 ; Perrenot de Chantonnay, 26 July 1561, LCM 1: 605 n. 2; Michele Suriano to the Doge of Venice, 28 July 1561, Despatches, 33-4

104 Thomas Randolph to William Cecil, 30 December 1562, in Calendar of State Papers Relating to Scotland and Mary, Queen of Scots: 1547-1603, ed. Joseph Bain (Edinburgh: H. M. General Register House, 1898), vol. 1: 674.
} 
stead" than that of her "'good mother' in France." Mary then expressed her doubts to Randolph about Catherine's ability to successfully rule France alone during the present troubles. ${ }^{105}$

Though Catherine's treatment of Mary during her residence in France was a major factor in why Queen of Scots responded to the queen regent's overtures with such cynicism, Catherine's souring relationship with the cardinal of Lorraine may have likewise negatively colored Mary's opinion of the Queen mother. In his correspondence to Cecil, Randolph mades mention of how Mary had taken "some despite against the Queen Dowager" for Catherine's "opinion" of the cardinal of Lorraine. ${ }^{106}$ Throughout the duration of Mary's reign, it seems that the cardinal was constant source of moral support and political advice for the Scottish Queen, and despite Catherine's evident desire to "keep up appearances" with Mary's uncle, it was well known that Catherine despised "[the cardinal of] Lorraine as much as any man alive. ${ }^{107}$

It was not until around 1565, after Mary had entered into her disastrous union with her cousin Henry Stuart, Lord Darnley and effectively alienated her Protestant nobility with attempts at the restitution of Catholicism in Scotland, that Mary began to positively receive and reciprocate those overtures made by Catherine and her son Charles IX. For instance, a few months after Mary's Protestant noblemen, led by Mary's bastard half-brother, James Stewart, earl of Moray, had declared open rebellion against the Scottish Queen's authority, Catherine and Charles sent the seasoned diplomat Michel de Castelnau, sieur de la Mauvissière to the Scottish court for the purpose of relaying Catherine's proposed "remedies for the troubles in [Mary's] realm." ${ }^{108}$ Catherine and her regency government would then continue to support the Queen of Scots, if only diplomatically, through the duration of this rebellion. Once Mary had safely

\footnotetext{
${ }^{105}$ Randolph to Cecil, 10 April 1563, CSP, Scotland 2: 4-5.

${ }^{106}$ Randolph to Cecil, 1-3 March 1562, CSP, Scotland 2: 133

${ }^{107}$ Monsignor Santa Croce to Cardinal Borromeo, 27 June 1563, Papal Negotiations, 449.

108“"French Ambassador" to Mary, Queen of Scots, 1 September 1565, CSP, Scotland 2: 200.
} 
returned from Sterling to Edinburgh after the suppression of this upheaval, the Scottish Queen wrote to King Charles, thanking him for the goodwill that he and the Queen mother borne towards Mary "en ce tamps de nos si grandes afferes."109 As Catherine was repairing her relationship with the Queen of Scots, the Queen mother likewise reached out to other members of the Guise clan. Upon hearing of the birth of Mary's son James in 1566, Catherine wrote a letter to Anne d'Este, duchess of Guise, stating that she could not be happier if Mary had been her "proper fille." ${ }^{110}$ In short, despite the initial mutual distrust between Catherine and Mary Stuart, Catherine was, at least in the last years of Mary's reign, doing quite well at incorporating Mary within her extensive diplomatic network, despite Mary's conflicting loyalties to Catherine's political enemies, the Guise.

However, regardless of Catherine's initial victories at the building of healthy rapport between the two queens, Mary Stuart would not reign in Scotland for much longer. Though Mary appeared to be reconciling with her estranged husband Lord Darnley, Mary's bellicose and potentially syphilitic consort was found strangled to death, most likely at the behest of Mary, in February 1567. Though both Catherine and Queen Elizabeth of England demanded that Mary seek out and punish Lord Darnley's murderers, a few months after Darnley's murder, Mary married James Hepburn, earl of Bothwell, who "public fame [had] charged with the murder" of Lord Darnley. ${ }^{111}$ Popular speculation held that Mary and Bothwell were not the only prominent conspirators in the demise of Lord Darnley. Even Don Francisco de Alava, the Spanish

\footnotetext{
${ }^{109}$ Mary, Queen of Scots to Charles IX of France, 26 October 1565, Papal Negotiations, 450.

${ }^{110}$ Catherine de' Medici to Anne d'Este, Duchess of Guise, 30 June 1566, LCM 2: 370.

${ }^{111}$ Elizabeth I of England to Mary, Queen of Scots, 23 June 1567, CSP, Scotland 2: 336.
} 
ambassador to the French court, wrote to King Philip that it was "Reyna (Catherine) y de Escocia fueron participes en la muerte de aquel Rey."112

Regardless of Catherine's supposed involvement in Lord Darnley's death, Mary's Protestant lords, disgusted by recent events and their Catholic queen's political ineptitude, imprisoned Mary in June 1567, in the reputedly "impregnable" castle of Loch Leven, while taking control of the town and castle of Sterling, where Mary's son Prince James was in residence. ${ }^{113}$ Mary would eventually escape her Scottish prison and crossed over the southern border into England, where she hoped that her cousin the queen of England would give her refuge from her Protestant nobleman and subsequently help her be restored to the throne. It seems that Catherine shared the same desires as Mary. Shortly after Mary's arrival in England, the Queen mother wrote to Queen Elizabeth, praying that Elizabeth "afford all the aid [Mary] needs to restore her to her liberty and authority." 114 Little would Catherine know, that this letter would be the beginning of nearly two decade diplomatic struggle that the Queen mother would wage in an attempt to emancipate her former daughter-in-law, and would-be political ally, from her captivity in England.

It became evident to both Catherine and Charles IX, that the English Queen had little intention of setting the Queen of Scots at her liberty in the fall and winter of 1568. In letters written to both the French King and the Queen mother, the French ambassador to the English court, Bertrand de Salignac de la Mothe-Fénélon, indicated that rather than releasing the Scottish Queen, Elizabeth was contemplating moving Mary further to the center of England from her location in the Castle of Bolton in Yorkshire, since there was fear that Catholic subjects in that

\footnotetext{
${ }^{112}$ Don Francisco de Alava to Philip II of Spain, 30 March 1567 in Relations politiques de la France et de l'Espagne avec l'Ecosse au XVIe siècle, ed. Jean Baptiste Alexandre and Théodore Teulet (Paris: Veuve J. Renouard, 1862), vol. $5,23$.

${ }^{113}$ Philibert du Croc to Charles IX of France, 21 June 1567, CSP, Scotland 2: 335.

${ }^{114}$ Catherine de' Medici to Elizabeth I of England, 26 May 1568, CSP, Scotland 2: 414.
} 
part of the country might attempt a rebellion on Mary's behalf. ${ }^{115}$ La Mothe-Fénélon then related in his letter to the Queen mother that 'qu'on mèneles afferes de la Royne d'Escoce avec tant d'artifice," and that all the "grands" at Elizabeth's court were preoccupied with Mary's destruction. $^{116}$

Despite the longevity of Mary's imprisonment, the tactics used by Mary’s French relatives to obtain her release, and likewise Queen Elizabeth's reaction to these ploys, seemed to follow an unvarying pattern for the nearly twenty years that Mary Queen of Scots was a captive of the English Queen. Of course, the frequency of the letters written by Catherine and her respective son's governments to Queen Elizabeth on the subject of Mary's liberation certainly oscillated in those two decades; however, the content of much of these letters remained the same. Either the Queen mother, or Charles IX or Henri III, depending on the year, would personally write to Elizabeth asking for the "honest and favorable" treatment of the Queen of Scots and requesting that Mary Stuart be "restored to her Realm with Authority due to her," or the French crown would have their ambassador at the English court express the same sentiments in a letter or in an audience with the English Queen. ${ }^{117}$ Depending on her mood, Elizabeth would then thank Catherine and her government for their concern for Mary's person, and go on to assert that she would do all in her power to restore Mary to her proper dignity. Alternatively, more frequently in the later years of Mary's imprisonment, the Queen of England would retort that Mary had been under a "noxious influence of some baleful planet" and that Scottish Queen had

\footnotetext{
${ }^{115}$ Bertrand de Salignac de la Mothe Fénélon to Charles IX of France, 22 November 1568, in Correspondance Diplomatique de Bertrand de Salignac de la Mothe Fénélon: Ambassadeur de France en Angleterre de 1568 à 1575, ed. Jean Baptiste Alexandre Théodore Teulet and Charles Purton Cooper (Paris and London: Béthune et Plon, 1838-1840), vol. 1: 13.

${ }^{116}$ La Mothe Fénélon to Catherine de' Medici, 22 November 1568, Correspondance Diplomatique 1: 15.

${ }^{117}$ Ibid., 68.
} 
brought her present troubles on herself. ${ }^{118}$ Regardless of Catherine's efforts, Mary Stuart would remain in England in until 1588. After Mary's complicity in a failed plot to overthrow Elizabeth was exposed, the English Queen finally executed her Scottish cousin much to the outrage of Catholic Europe.

Despite Catherine's evident failure to incorporate Mary Stuart into her political network, it is important to note that, regardless of Scottish Queen's eventual fate, there were legitimate indications that Catherine's aid and involvement in Mary's cause might have exponentially improved the diplomatic position of the French crown, when there was internal religious turmoil at home. Some of these better known reasons can be found in memorandum entitled, the "Affairs of Scotland," which was written by Elizabeth of England's Secretary of State Lord Burghley speculated as to some of these reasons why the French King Charles IX, and likewise Catherine, since the Queen mother ruled for and with her young son for the majority of his reign, sought the delivery of Mary Stuart. In spite of Cecil's obvious political biases, his assessment of French crown's motivations appears to be politically sound. Though Charles was evidently not fond of the Scottish Queen, Cecil believed that one of the reasons why the French King took up Mary's cause was because Charles IX did not want his reputation to be damaged for seemingly abandoning his dead brother's wife. ${ }^{119}$ According to Cecil, the French crown also feared that Mary's overthrow by her subjects might set a dangerous precedent that Charles' own subjects would be tempted to follow. Cecil also speculated that, in addition to maintaining the centuriesold Auld Alliance, the French crown also sought to appease the perpetually troublesome house of Guise. The final reason that Cecil gave for the Valois support of Mary during this time, and the one that he emphasized the most, deals with the potential interference of the king of Spain. In

\footnotetext{
${ }^{118}$ Elizabeth I of England to Catherine de' Medici, 16 February 1567, in The Letters of Queen Elizabeth I, ed. G.B. Harrison (London: Cassell, 1968), 51-2.

${ }^{119}$ Lord Burghley (Cecil), 30 April 1572, CSP, Scotland 4: 272.
} 
Cecil's opinion, the French King, and one can assume the Queen mother as well, feared that if Philip were successful at helping Mary Stuart regain her throne, the crown of Spain and the crown of Scotland would be firmly knit in amity to the detriment of French interests. ${ }^{120}$

Of course, there are addition reasons that Catherine and her sons Charles IX, and then Henri III, would have had for supporting the Queen of Scots in her endeavors, which Cecil would have neglected to go into detail about in a memorandum that would have been presented to either Queen Elizabeth or her Privy Council. Despite Catherine's numerous attempts to marry her youngest sons to the English Queen, relations with Elizabeth were never completely cordial. Even before the St. Bartholomew's Day, which strained relations between the French crown and Protestant England, Catherine received reports from La Mothe-Fénélon recounting the "mauvaises deportements dont [Elizabeth] et ses subjectz avoient uzé contre" Catherine and Charles. ${ }^{121}$ Therefore, Catherine may have been seeking the restitution to the throne of a potential ally against Elizabeth, should the situation arise, in addition to building a healthy rapport with Catholic Europe's preferred candidate for the English throne.

In spite of the great diplomatic potential that the Scottish Queen could have had in conjunction with Catherine's interests, the case of Mary Stuart, Queen of Scots is perhaps the most salient example of the weaknesses of Catherine's political network. In the years prior to Mary's return to Scotland, both Catherine's personal sentiments towards the young Queen of Scots as well as Mary's conflicting loyalties to Catherine's enemies, the house of Guise, prevented Catherine from seizing the opportunity to incorporate the monarch of France's oldest ally within her political sphere. Also, during the first years after Mary's return, the Queen of Scots involvement within the "Guise affinity" likewise precluded Catherine's former daughter-

\footnotetext{
${ }^{120}$ Burghley (Cecil), 28 March 1572, CSP, Scotland 4: 209.

${ }^{121}$ La Mothe Fénélon to Catherine de' Medici, 8 March 1569, CSP, Scotland 1:223.
} 
in-law's absorption within Catherine's network. Then, when Mary Stuart was removed from the throne and imprisoned, she was of little use to Catherine because she had neither military strength nor political clout. All the Queen of Scots possessed was a popular religious following, and the tenuous support of Catholic monarchs who were not incensed enough about her predicament to go to war with England. Of course, Catherine cannot be blamed for her desire to maintain a relationship with her former daughter-in-law. As previously mentioned, Catherine had numerous incentives for advocating the release of the Queen of Scots. Therefore, Catherine should not be censured for not having realized that, as Queen Elizabeth of England so eloquently put it, "the bark of [Mary's] good fortune [floated] on dangerous seas." 122

\section{Elisabeth of Austria}

Though Catherine de' Medici had little input in the betrothal of her eldest son François to the Queen of Scots in the 1548, Catherine's position as Queen regent for the large part of the 1560s ensured that she would have an integral role in the brokering of her second son Charles's marriage. Charles, as previously mentioned, married Elisabeth of Austria, the second eldest daughter of the Holy Roman Emperor Maximilian II in November 1570. Born on July 5, 1554, the "beautiful" and "agreeable" Elisabeth of Austria may have not been the favorite daughter of the Emperor Maximilian, but the young archduchess, along with her elder sister Anne, were two of the most sought after young brides in Europe at the time as well as the first female royals whom Catherine pursued in earnest on behalf of her young son. ${ }^{123}$ However, regardless of her positive personal attributes, as well as her relation to one of the most powerful monarchs in Europe at the time, it seems that Catherine's acquisition of Elisabeth for her young son yielded

\footnotetext{
${ }^{122}$ Queen Elizabeth I of England to Mary Stuart, Queen of Scots, 25 May 1569, Letters of Queen Elizabeth I, 56.

${ }^{123}$ Brantôme, Illustrious Dames, 262.
} 
little substantial gains for the French crown in the way of foreign policy. Therefore, like the previous section on Mary, Queen of Scots, this section concerning Elisabeth of Austria will likewise seek to examine why Catherine sought to incorporate this particular royal female into her network, and how despite her initial intentions and best efforts, Catherine was unable to effectively utilize her Austrian daughter-in-law to her advantage.

Despite the French Queen mother's later enthusiasm for the union, it seems that during the summer of 1568, both Emperor Maximilian, and oddly enough Catherine, hoped for another match for the Archduchess Elisabeth. In a letter written to Catherine from Fourquevaux, the French ambassador to the Spanish court indicates that Maximilian was close to sending the Archduchess Elisabeth to the Portuguese court, so that she may marry King Sebastian. Rather than expecting the Queen mother to be distressed at this news, Fourquevaux hints that this was what Catherine desired at the time. Evidently when the letter was written, Catherine hoped for a marriage between Marguerite and the Archduke Rudolf, who though not yet officially elected, was going to be the next Holy Roman Emperor. Though not implicitly stated, Fourquevaux's letter suggests that perhaps the Emperor did not favor a double alliance between his house and France, and since Elisabeth was set to be the queen of Portugal, taking her out of the running for Charles IX's bride, Catherine may have hoped that the more desired match between Marguerite and Rudolf could now come into fruition. Evidently, Catherine found it more politically advantageous to have her daughter be the Holy Roman Empress, than have her daughter-in-law be the issue of the Holy Roman Emperor. ${ }^{124}$

It seems that by January 1569 Catherine was no longer desirous to see the Archduchess Elisabeth married to the king of Portugal. Apparently abandoning her hope for a union between Marguerite and the Archduke Rudolf, Catherine now sought, as mentioned in the previous

\footnotetext{
${ }^{124}$ Fourquevaux to Catherine de' Medici, 23 August 1568, LCM 3: 173-4 n. 1.
} 
chapter, to marry Marguerite to King Sebastian. However, instead of seeking Elisabeth as a bride for her son, Catherine instead pursued Elisabeth's sister Anne for King Charles. ${ }^{125}$ The eldest and favorite daughter of the Emperor, it understandable the Catherine turned her intention to the Archduchess Anne, since the Emperor's preference for his eldest daughter would have undoubtedly better benefited the maintenance of a stable relationship between the Valois and the Austrian Habsburgs. However, regardless of Catherine's intentions, Fourquevaux wrote to Catherine explaining not only that it appeared likely that the King of Portugal would marry the Archduchess Elisabeth, but that the newly widowed King Philip of Spain seemed inclined to marry the Archduchess Anne, and nearly a year later, Philip did just that. ${ }^{126}$

Yet, fortunately for Catherine, the loss of Anne to her former son-in-law Philip was partially mollified by the acquisition of Elisabeth for Charles. The marriage itself took place on November 26, 1570, and during the wedding ceremony it was Catherine who took Elisabeth's hands and placed them between those of King Charles. Though Catherine had initially been disappointed at losing Anne to King Philip, it appears that Catherine was actually encouraged by the turn events, since Elisabeth was “'d'un naturel fort simple, qui se lairroit mener comme on vouloit." $" 127$

During her short tenure as Charles IX's consort, Queen Elisabeth became loved and respected for her pious and compassionate character and quickly acquired the respect of the people. In short, despite the reputedly debaucherous character of the Valois court during the period, Elisabeth, it seems, remained "toujours irreproachable." ${ }^{128}$ However, unfortunately for Elisabeth's mother-in-law, being loved and respected by the French people is not the same thing

\footnotetext{
${ }^{125}$ Catherine de' Medici to Fourquevaux, 15 November 1568, LCM 3: 205.

${ }^{126}$ Fourquevaux to Catherine de' Medici, 1569, LCM 3: 221-2 n. 2.

${ }^{127}$ Michel Simonin, Charles IX (Paris: Fayard, 1995), 241.

${ }^{128}$ Abel Desjardins, Charles IX: Deux Années de Regne, 1570-1572 (Paris: Douai, 1873), 22.
} 
as being politically influential or useful to the French crown. Though Elisabeth became pregnant shortly after her marriage to King Charles, and subsequently gave birth to a daughter, MarieElisabeth, in November 1572, there would be no further issue from her marriage with Catherine's son. ${ }^{129}$

In addition to failing in her principal duty to provide the realm with a male heir, Elisabeth was likewise unable to establish a strong political footing at the Valois court. Elisabeth never mastered the French language; instead she spoke Spanish, and despite being respected by the courtiers, her reserved manner often caused her to be isolated in France. The evidence also seems to indicate that she exercised comparatively little influence over her father the emperor or her Habsburg relatives.

When Catherine sent diplomatic missives to king of Spain or Navarre, the Queen mother would often refer to or inquire after her daughters, indicating that Élisabeth and Marguerite were supposed to serve as physical reminders of a diplomatic union between the French crown and the two respective kingdoms. Yet, in the correspondence between Catherine and both the emperor and the queen of Spain, who was Elisabeth's sister, the virtuous and pious consort of Charles IX is rarely mentioned. Of course, surviving correspondence between the Catherine and figures at the Spanish and Navaresse courts is both more numerous and topically diverse, therefore, the chances of finding letters that show Catherine's use of her eldest daughter are much more numerous. However, regardless of this fact, the mention of Elisabeth of Austria, in either an affectionate way or as a participant in court politics, occurs very infrequently within the correspondence between the French crown and either the Austrian or Spanish Habsburg houses.

Yet, if one takes Catherine's claim that her primary desire in brokering the marriage between Charles and Catherine was to preserve peace between the French king and the emperor,

${ }^{129}$ Charles IX of France to Jean de Vivonne, seigneur de Saint-Gouard, 8 February 1573, LCM 4: 161 n. 1. 
then she was successful. For the four years during which Charles and Elisabeth of Austria were married, France and the Holy Roman Empire were indeed at peace, though in the years prior to match, there was very little indication that war was imminent between the two states. Therefore, despite the more modest reasons that the Queen mother professed for pursuing this marriage, it is highly unlikely that her sole objective in seeking this union was the maintenance of peace with an outwardly non-belligerent power.

Though never implicitly stated by Catherine in her published correspondence, one can speculate, given the larger diplomatic issues of the period, what Catherine's ulterior motives may have been. As indicated in the earlier chapter, the Queen mother had hoped that the Emperor would be able to curtail the entrance of German mercenaries into France on the side of the Huguenots during the Second War of Religion in $1568 .{ }^{130}$ Also, during the negotiations for the marriage between Charles and Elisabeth, it was made evident to Maximilian that, in order for this marriage to take place, all imperial mercenaries serving the Huguenot cause needed to quit France. Despite the Emperor's apparent urging that the mercenaries leave France, it seems that the emperor was able to do relatively little to alleviate the internal pressures suffered by the French crown. ${ }^{131}$ Another potential reason that Catherine could have had for seeking the hand of Elisabeth of Austria was to seek to reorient Austrian diplomatic policy away from its Spanish cousins and towards its geographic neighbors, the French. If that were the case, the marriage likewise failed to achieve this objective. The Austrian and Spanish Hapsburgs, regardless of moments of discord, would be allied for the next century. The marriage between King Charles and Elisabeth likewise failed to prevent and or assuage further political disagreements between the French crown and the emperor. For instance, the Emperor Maximilian refused to recognize

\footnotetext{
${ }^{130}$ Emperor Maximilian II to Charles IX of France, 1568, LCM 3: $195-7$ n. 1.

${ }^{131}$ Paula Sutter Fichtner, Maximilian II (New Haven, CT: Yale University Press, 2001), 182.
} 
Catherine's cousin, Cosimo de' Medici, as Grand Duke of Florence. ${ }^{132}$ Catherine and Maximilian likewise locked horns over their sons' election to the Polish throne. Rather than supporting Henri, duke of Anjou's candidacy, the Emperor put forth his eldest son, the Archduke Rudolf, for the position, and was supported in these endeavors by the king of Spain. ${ }^{133}$

Of course, the marriage was not a complete loss. As already mentioned, a state of military peace existed between the France and the Holy Roman Empire for the short duration of Charles' and Elisabeth's marriage, which in retrospect, was a politically sound achievement, since a combined invasion of Spanish and Austrian forces, however unlikely, would have had deleterious results for France. Catherine was also known to have used Elisabeth's name in her diplomatic wrangling with the emperor. When the emperor refused to acknowledge Cosimo de' Medici as the grand duke of Florence, Catherine wrote to Jean de Vulcob, her ambassador to the Imperial court, stating that she spoke to her daughter-in-law, asking Elisabeth to write to her father the emperor on behalf of Catherine's cousin Cosimo. ${ }^{134}$

However in the end, it seems that the match for which Catherine had worked tirelessly yielded few gains for either the French crown or the aggrandizement of her own political influence. Not only did Elisabeth not provide her husband with a male heir, she seems to have had very little political clout with either her father or her husband, and the existence of the match itself was not enough to preclude disagreements between the Emperor and the French government. Of course, the last thing that Catherine needed in her court was a politically vocal or adept daughter-in-law, who could have acted as an advocate for Habsburg interests at the French court. Indeed, the fact that Catherine filled Elisabeth's household with Catherine's own "creatures" suggests that the Queen mother, at least initially, feared just that. Though it is

\footnotetext{
${ }^{132}$ Catherine de' Medici to Jean de Vulcob, 22 September 1571, LCM 4: 68-9.

133 Arnaud du Ferrièr to Catherine de' Medici, 16 September 1572, LCM 4: 132-3 n. 1.

${ }^{134}$ Catherine de' Medici to Vulcob, 22 September 1571, LCM 4: 69.
} 
tempting to believe that Catherine neglected or was unable to use Elisabeth to her benefit, because Elisabeth was already part of the extensive Habsburg political network, it seems that Catherine had no issue capitalizing on her relationship with other Habsburg women. In fact, Catherine wrote numerous letters to Elisabeth's sister, the queen of Spain, on a wide variety of political matters which Catherine evidently hoped the queen of Spain would pass on to her husband. So in the end, it seems the most likely cause of Catherine's failure to incorporate Elisabeth within her own political network was the personality and temperament of her daughterin-law, as well as the relatively brief duration of her marriage to King Charles.

\section{Louise de Lorraine-Vaudémont}

Similar to her sister-in-law Elisabeth of Austria, Louise de Lorraine-Vaudémont was reputed by her contemporaries and remembered by history as being a "beautiful," "chaste and pious" wife and then widow. ${ }^{135}$ The daughter of Nicholas de Lorraine, duke of Mercœur and his first wife Marguerite d'Egmont, Louise de Lorraine-Vaudémont had the lowest pedigree of Catherine's daughters-in-law, even though Louise was both the niece of Charles III, duke of Lorraine and distantly related to powerful Guise clan. However, it seems that political necessity factored very little in the choice of Louise as the next queen consort of France. As the story goes, Henri III, then the duke of Anjou, was en route to Poland when he stopped at the court of Duke Charles. During his short sojourn in Nancy, the young and beautiful Louise caught his attention since she greatly resembled Henri’s previous romantic attachment, Marie de Clèves, princess of Condé, who had recently died after giving birth to the prince of Condé's daughter that

\footnotetext{
${ }^{135}$ Brantôme, Illustrious Dames, 281.
} 
October. ${ }^{136}$ After returning to France following the death of Charles IX, King Henri III, remembering the young woman at Nancy, became resolved to espouse Louise, and the couple was married in February 1575. ${ }^{137}$

What were Catherine's feelings about her son's intended mésalliance with a woman of comparatively low pedigree, who was also related to her perpetual political enemies, the house of Guise? Not surprisingly, Catherine initially did all in her power to thwart that match. Catherine had higher aspirations for her son than the mere niece of the duke of Lorraine, and before Henri III had resolved to marry Louise, Henri de Valois had been offered the hand of multiple ladies from much grander houses, including his former sister-in-law Elisabeth of Austria, Queen Elizabeth of England, Catherine de Bourbon, who was the king of Navarre's sister, and princesses from both Sweden and Denmark. ${ }^{138}$ As for Louise's affiliation with the house of Guise, Catherine was still ever fearful of their influence on their female members of their clan. ${ }^{139}$

Regardless of Catherine's initial opinions of the match, by the time that Henri III began sending out official announcements of his engagement to all the European heads of state, Catherine appeared to be the marriage's greatest proponent, and in fact, took credit for it. ${ }^{140}$ In a letter written to the king of Spain, Henri III explains to Philip that, in marrying Louise, he is in fact following the implorations of his mother to marry. ${ }^{141}$ In addition to the letters written by Henri to various heads of state, Catherine would write her own missives announcing the impending marriage between Henri and "la fille de Monsieur de Vauldemont" to the duke Savoy

\footnotetext{
${ }^{136}$ Le comte de Baillon, Histoire de Louise de Lorraine : Reine de France, 1553-1601 (Paris: Chez Léon Techener, Libraire, 1884), 40 ; Pierre de L'Estoile, Journal pour le règne de Henri III (1574-1589), ed. L.-R. Lefèvre (Paris: Gallimard, 1943), 48.

${ }^{137}$ L'Estoile, 14 February 1575, Journal, 67.

${ }^{138}$ Baillon, Histoire, 41.

${ }^{139}$ Dr. Valentine Dale to Sir Francis Walsingham, 13 February 1575, LCM 5: 112 n. 1 (See second column).

${ }^{140}$ Dale to Burghley (Cecil), 5 March 1575, LCM 5: 112 n. 1 (See second column).

${ }^{141}$ Henri III to Philip II of Spain, Lettres de Henri III: Roi de France, ed. Pierre Champion and Michel François (Paris: C. Klincksieck 1959), vol. 2: 107-8.
} 
and the king and queen of Spain, among others, and in each letter, Catherine speaks approvingly of the match.

Catherine's change of heart can possibly be explained in three ways. First, the Queen mother's behavior, at least in regards to her optimistic tone in these letters, is probably the result of Catherine's desire to seem like she still had influence over her son's political decisions, even though Henri III clearly chose Louise solely "pour [son] contentement." ${ }^{\text {"142 }}$ Ascending to the throne at the age of twenty-three, Henri III was the only one of Catherine's sons who was not compelled to rule with a regency of some form. Therefore, Catherine may have been trying to give the impression that she still held significant power at court, despite that fact that she no longer had any official authority over her son. The second reason why the Queen mother may have come to accept the marriage is because she was desperate for Henri III to marry and to produce a male heir to ensure the prolongation of the House of Valois. As she explained to King Philip, Louise was "belle" and "de age pour bientost avoyr lignée," and perhaps Catherine predicted that Henri III's decidedly amorous intentions towards his future wife would be conducive to the production of an heir. ${ }^{143}$ The final motivation that could have induced Catherine into accepting Louise as her daughter-in-law was that Catherine was seeking to fill a hole recently left within her political network. Catherine's second eldest and favorite daughter Claude de Valois, wife of the Duke of Lorraine, died in childbirth on February 21, 1575, a few weeks before the intended marriage between Henri and Louise. Though Claude's death would not have been the cause of Catherine's more positive outlook on the marriage in the aforementioned letters written to the duke of Savoy and the king and queen of Spain, the passing of Claude may have caused Catherine to be further retrospective on the potential benefits of Henri's marriage to

\footnotetext{
${ }^{142}$ Henri III of France to Bellièvre, 5 February 1575, Lettres de Henri III 3: 106.

${ }^{143}$ Catherine de' Medici to Philip II of Spain, 16 February 1575, LCM 5: 11.
} 
Louise. Catherine no longer had a loyal ally placed within the House of Lorraine, and perhaps Catherine hoped that Louise could serve in a diplomatic capacity similar to Claude.

Regardless of Catherine's motivations for finally approving this marriage, it seems that like her predecessor Elisabeth of Austria, Louise de Lorraine-Vaudémont would prove to be a disappointment to Catherine. Despite the fact that Henri III was evidently attentive to Louise, at least in the early years of their marriage before he shunned her bed for religiously motivated reasons, Louise remained barren throughout the duration of their marriage. In his journal covering the reign of Henri III, Pierre de l'Estoile recounts how both the king and queen would make frequent pilgrimages in the hopes the imploring God and or the Virgin Mary to bestow on them a healthy son. ${ }^{144}$ L'Estoile does not mention Catherine's response to Louise's barren state, however courtesy of Amias Paulet, another English ambassador to the French court, we know that Catherine was looking to supplant Louise with a younger and perceivably more fertile princess as early as 1578, even though "the Queen mother was once in danger of having the like practiced against her." According to Paulet, Catherine was "treating with the Spaniard (Philip II)," in an attempt to acquire one of Catherine's granddaughters by Élisabeth de Valois for her son King Henri. ${ }^{145}$

If Catherine had hoped that Henri III's marriage to Louise would likewise mitigate the latent hostility between the French crown and Guise clan, she would be severely disappointed in this regard as well. Of course, historian Chantal Clément has recently asserted that Louise's position as queen of France helped build amicable relations with the house of Lorraine, however,

\footnotetext{
${ }^{144}$ L'Estoile, 7 January 1583, Journal, 320.

${ }^{145}$ Amias Paulet to the Secretaries, 22 November 1578, in Calendar of State Papers: Foreign Series, of the Reign of Elizabeth, 1578-1579. ed. Arthur John Butler (London: Public Record Office, 1903), vol. 13: 302.
} 
it seems that whatever rapprochement the crown and the Guise achieved during Louise's tenure as Queen quickly evaporated by the mid-1580s. ${ }^{146}$

One of the most notable attempts by Henri III to align himself "to the Ultra-Catholic Guise faction" was through the marriage of Louise's younger half-sister, Marguerite de LorraineVaudémont, to one his “mignons," Anne de Batarnay, duke of Joyeuse. ${ }^{147}$ Though popular rumor held that Joyeuse, like Henri's other male favorites, was in fact the king's lover, the elevation of previously low-ranking Joyeuse and other such mignons was more likely an attempt by Henri III to create a new, more loyal, sector of the nobility that owed its position only to the King. Therefore, in marrying Joyeuse to Marguerite de Lorraine-Vaudémont, Henri III was either attempting to legitimate Joyeuse's new social status through a marriage to a foreign princely house, or, Henri III was trying to connect his newer nobility (Joyeuse) to his older nobility (the house of Lorraine). Regardless, Joyeuse and Marguerite de Lorraine-Vaudémont were married in September 1581, and their wedding followed with days of sumptuous and ruinously expensive masquerades and tournaments. ${ }^{148}$ It is difficult to determine what role, if any, Catherine had in the fruition of this marriage; however, it seems that Catherine had at least endorsed it after the fact. Though it would never be performed, there is also some indication that Catherine attempted to plan a fête as part of the exorbitantly lavish ceremonies following the wedding. ${ }^{149}$

Despite providing ample entertainment for Henri's courtiers, the marriage itself would do little in the way of improving the crown's relations with the house of Lorraine and Guise, as in the case with most other attempts made by Henri III and Catherine to put Louise's relatives in positions of power within both the French kingdom and the church. Despite being personally

\footnotetext{
${ }^{146}$ Chantal Clément, Louise de Lorraine-Vaudémont, reine de France (Paris: Plume du temps, 2002).

${ }^{147}$ Roy C. Strong, Art and Power: Renaissance Festivals, 1450-1650 (Berkeley, CA: University of California Press, 1984), 117.

${ }^{148}$ L'Estoile, 7 September 1581, Journal, 274.

${ }^{149}$ Hoogvliet, "Princely Culture," 126.
} 
recommended by Catherine for the bishopric of Toul in 1580, which he successfully acquired, Louise's younger half-brother Charles de Lorraine-Vaudémont, cardinal of Vaudémont, was one the founders of the Holy League that would seek to "exterminer les premiers de la maison de Bourbon, et les plus proches de la couronne, pour faire ouverte profession de ladite religion prétendue reformée." 150 Philippe-Emmanuel de Lorraine-Vaudémont, duke of Mercœur, was another younger half-brother of Louise who would, despite being bestowed with lucrative positions by his brother-in-law, set both his own interests and those of the house of Lorraine over those of the French crown. Given the governorship of Brittany by King Henri in 1582, Mercœur would withdraw from court with his Guise relative the duke of Mayenne in March 1587 and would retake control of province on behalf of the League. ${ }^{151}$ Ironically enough, Louise's sister, Marguerite de Lorraine-Vaudémont, who had been married to Henri III's favorite the duke of Joyeuse in 1582, would also join the League after the death of her husband. Due to her sibling's defection to the League, Henri III's consort was also suspected of having Leaguer sympathies during the lifetime of her husband. However, Louise would remain loyal to King Henri, even after the excommunication of the King following the murder of the duke of Guise, and would continue to petition the Pope to lift the bull of excommunication until her death in $1601 .{ }^{152}$ In summary, regardless of their varying pedigrees, Catherine de’ Medici initially saw a place for all of her daughters-in-law within her own extensive political system, though many of Catherine's ambitions for her daughters-in-law were left unrealized due to their simultaneous existence within one or more political networks, as well as other situational contributing factors. Catherine probably had little to no role in the brokering of the marriage between the young Scottish Queen and François II, but, it seems that after Mary returned to Scotland and had been

\footnotetext{
${ }^{150}$ Catherine de' Medici to Louis d'Abain, 29 January 1580, LCM 7: 222; L'Estoile, Journal, 375.

${ }^{151}$ L'Estoile, Journal, 29 March, 488; L'Estoile, Journal, 7 June 1589, 634.

${ }^{152}$ Brantôme, Illustrious Dames, 283.
} 
separated from her scheming Guise relatives, Catherine made great strides at mending their seriously strained relationship, and after Mary's imprisonment in England, Catherine tirelessly fought for the Scottish Queen's release. Regardless of these best efforts, it seems that Catherine's hopes for utilizing Mary's position were dashed by events that were out of her control. Though Catherine's goals for Elisabeth of Austria are much less discernable than Mary Stuart's, it seems that Elisabeth's marriage to Charles, a union that variously worked for, likewise yielding few tangible gains for the French crown and for the maintenance of Catherine's own influence. Yet, unlike in the case of Mary, Queen of Scot, whose political ineptitude and position as a reigning Queen were the primary factors that prevented Catherine for effectively using Mary, it seems that in the case of Elisabeth of Austria, it was Elisabeth's reserved temperament, in addition to her comparatively short marriage that prevented her from developing a position of political influence at court. As for Louise de Lorraine-Vaudémont, it was most likely her barren state throughout her marriage, as well as the unpredictability of her Guise and Lorraine relations that prevented her from being of any substantial use to Catherine. However, regardless of these varying factors, it seems that all three daughters-in-law possessed one similarity that contributed to their political effectiveness, or lack thereof, for Catherine: their concurrent existence within more than one dominant political network. 


\section{Chapter 3: The Flying Squadron}

While Catherine de' Medici was attempting to capitalize on her daughters' positions of power within foreign courts and the perceived political connections of her daughters-in-law, the Queen mother was also incorporating an assortment of noblewomen of varying rank and economic standing within her political network. However, unlike Catherine's political relationship with her daughters and daughters-in-law which was more of a kinship-based system centered on notions of personal loyalty and familial responsibility, the Queen mother's association with the noblewomen of her court for political gain resembles more of a traditional patron-client network, in which "court noblewomen brokered royal patronage for personal profit and to advance their families and dependents."153

Throughout much of her tenure as Queen mother, Catherine had upwards of two hundred noblewomen in her service. Though the majority of them acted in more traditional capacities functioning as both social companions and domestic servants, Catherine also used those ladies who possessed certain special qualities in her quest to consolidate her own political influence. These particular qualities included physical beauty and personal charm, as well as a high degree of noble rank and economic influence inherited from their fathers or acquired through marriage. Private ambition on the part of the woman and her family played an integral role in the lady's acquiescence to Catherine's machinations, yet an obvious sense of public duty to the crown and the Queen mother was likewise desired by Catherine. Personal loyalty, or at least the appearance of personal loyalty, was an important component in the composition of Catherine's network of court ladies. However, the main ties that bound these women to the Queen mother and her political agenda was the prospect of economic wealth and increased political influence for

\footnotetext{
${ }^{153}$ Kettering, Patronage Power of Noblewomen, 819.
} 
themselves and their relatives, and due to her status as both Queen mother and regent, Catherine de' Medici possessed almost unprecedented patronage powers for a woman at the French court.

As such, this chapter's main focus will be on the Catherine's patron-client relationship with the noblewomen at the French court, how she sought to use these ladies for her benefit, and how she ensured their participation in her political machinations. Like the previous two chapters, this segment, rather than being a more generalized study, will be centered on Catherine's utilization of individual women. Focusing on two members of the infamous "escadron volant," Louise de La Béraudière, also known as "la belle Rouhet" and Charlotte de Sauve respectively, this chapter will seek to explain how Catherine used their immense sexual appeal to placate and immobilize troublesome noblemen, when the continuance of Catherine's own political authority was in question.

Despite Catherine de' Medici's significant reliance on noblewomen of all ranks to realign domestic politics to her benefit, it is perhaps Catherine's use of a certain sector of her ladies, known popularly to posterity as the "escadron volant," or "flying squadron," that gains the most attention within the scholarship of this period. As popular legend contends, the "escadron volant" was essentially a bevy of beautiful, lower-ranking noblewomen used by Catherine to seduce potentially troublesome noble magnates. Though Catherine's use for each member of the squadron varied depending on which noble mark a particular lady had been assigned, the Queen mother usually had one of two objectives in placing squadron member before a male grandee. The first and most obvious was to reveal the political maneuverings of these noblemen which may have run contrary to Catherine's own designs and the second was to create dissention between a particular nobleman and his political allies. With their souls "poisoned" and their 
consciences "dulled," these men likewise became more politically lethargic as a result of their dalliances with these women, making them more amenable to Catherine's agenda. ${ }^{154}$ Regardless of the frequent, though not thorough, discussion of the "flying squadron," much of the secondary works that touch upon this group of court women, especially during the nineteenth-century, profligates the "Black Legend" surrounding Catherine and her children. This was the result of either the religious and political biases of the historian, or the author's attempt to satisfy the public's cravings for tales of sexual immorality and political intrigue concerning long-dead French royalty. In addition to tailoring their findings to suit their own biases and the public's preferences, these works were also inadequately cited and poorly researched. Footnotes and other forms of citations are rarely found in scholarship that mentions members of the "flying squadron," and when sources are included by the author, they are usually earlier secondary works published years after Catherine's death. Despite Margriet Hoogvliet's assertion that Catherine's ladies "have been associated too easily with sexuality by modern scholarship," it seems that more recent serious studies of Catherine and her court avoid discussing the "flying squadron" at length, if they mention it at all. ${ }^{155}$ This is most likely due to the reticence of rigorous scholars to publish theories that cannot be supported by sufficient evidence.

Regardless of the lack of primary sources mentioning Catherine's utilization of these court women, larger conclusions about the function of the flying squadron can still be reached through a more thorough reading of existing sources. Though it is still difficult to determine what directives, if any, came from Catherine, we can still make conjectures on the flying squadron's function within the Queen mother's network, as well as its impact on court politics, by following patterns of behavior among the targeted grandees. In other words, we can measure the political

\footnotetext{
${ }^{154}$ Eugène Bersier, Coligny: The Earlier Life of the Great Huguenot (London: Hodder and Stoughton, 1884), 218.

${ }^{155}$ Margriet Hoogvliet, "Princely Culture," 125.
} 
impact of the flying squadron by examining the political activities of these noblemen, and their stance towards Catherine's governmental policy, before and after they had been introduced to a particular member of the "flying squadron."

\section{Louise de La Béraudière: "la belle Rouhet"}

Though she may have not been the founding member of the flying squadron, Louise de La Béraudière, known affectionately within the court as "la belle Rouhet," was certainly one of the first, and likewise most famous, filles d'honneur that the politically vulnerable Queen mother used to manage her high-ranking noblemen. ${ }^{156}$ Like many members of the "flying squadron," many of the particulars of Rouhet's early life are relatively unknown. Rouhet was the daughter of a Poitevin nobleman Louis de La Béraudière, seigneur de Sourches and Rouhet and marquis de l'Isle-Jourdain. Born sometime in 1538, as most genealogical works assert, the unmarried Rouhet was most likely in her late teens to early twenties when she began her court career, where she gained great notoriety for her beauty. According to Brantôme, such was Louise's physical appeal, that if the legendary Roland were still alive, his love for her would defy "les cieux." ${ }^{157}$ It is difficult to pinpoint when exactly Catherine offered up her pretty provincial fille d'honneur to Catherine's most pliable and unpredictable noble ally, Antoine de Bourbon, King of Navarre. However, it seems likely that the sexual relationship between Antoine and Rouhet began a few months prior to Antoine's death in November 1562, resulting in the birth of Antoine's illegitimate son in $1563 .{ }^{158}$

However, just because there is a relative dearth of primary evidence discussing Mademoiselle de Rouhet's dalliance with the king of Navarre, that does not mean that her place

\footnotetext{
${ }^{156}$ Brantome, Oeuvres complètes de Pierre de Bourdeille. ed. Ludovic Lalanne. (Paris: Libraire Renouard, 1881), vol. 10, 392 .

${ }^{157}$ Ibid., 428 .

${ }^{158}$ Alphonse de Ruble, Antoine de Bourbon et Jeanne d'Albret: suite du mariage de Jeanne d' Albret. vol.4. (Paris: A. Labitte, 1886), n. 374.
} 
in Catherine's political network and her role in court politics must remain shrouded in mystery. Rather, this lack of sources directly discussing Rouhet only necessitates a different way of approaching existing evidence. As previously indicated in the introduction of this chapter, one can gauge the political influence of a member of the "flying squadron" by examining patterns of behavior and the evolution of personal political policy before and after the commencement of a lady's affair with a noble magnate. Therefore, this section will not so much be a discussion of Rouhet's life and court career, but rather, a comparative analysis of Catherine's and the king of Navarre's political relationship before and after Navarre's introduction to Rouhet. What crises in foreign diplomacy, domestic policy and court factionalism involving the king of Navarre caused Catherine to solicit Rouhet to seduce Antoine de Bourbon, and did these political issues begin to improve in Catherine's favor after the king of Navarre began his affair with "la belle Rouhet?"

Why would Catherine solicit Rouhet to ensnare the King of Navarre, and what positive effect, if any, did Rouhet's affair with Antoine have on the Queen mother's ability to control this Bourbon prince? In addition to being the first prince of the blood, and therefore heir to the French throne if the male Valois line should become extinct, Antoine was the husband of the newly converted queen regnant of Navarre, Jeanne d'Albret, a woman who would become one of Catherine's greatest political and religious rivals. Though the king of Navarre never officially converted, the religious proclivities of Antoine's wife and younger brother, as well as his embrace of certain Calvinist practices, caused many European Protestants to view him as the titular head of the Huguenot movement in France, despite his continued mass attendance and his own professions of religious orthodoxy. ${ }^{159}$ Yet, despite Antoine's initial high standing within Calvinist circles, which could have provided him a base of political and military support both

\footnotetext{
${ }^{159}$ N.M. Sutherland, "Antoine de Bourbon, King of Navarre and the French Crisis of Authority, 1559-1562" in
} Princes, Politics and Religion: 1547-1589 (London: Hambledon Press, 1984), 57-8. 
within France and abroad if he had chosen to capitalize on his position, and despite his prominence within the line of succession, it seems that the king of Navarre never achieved a degree of authority consistent with his rank or that likewise satisfied his own ambitions.

Therefore, in his quest for greater political influence, Antoine frequently changed political affiliations, entering into schemes with other noble magnates that often undermined Catherine's own political program.

Regardless of Antoine's later political betrayals, it seemed, at least during the uncertain days of François II's reign, that Catherine could depend on the Bourbon prince to help counteract Guise political hegemony. When the Guise brothers assumed control of the government following the death of Henri II, the Queen mother was not the only individual who had had their authority snatched from them. After the king of Navarre returned to the French court, the feud between the first Prince of the Blood and the Guise brothers continued to fester, and in June 1560, an attempt was made on Antoine's life by “instruments of the Guises." 160 This assassination attempt was then followed by the imprisonment of Antoine's brother the prince of Condé by the Guise-led royal council on charges of heresy and rebellion in November of the same year due to his perceived involvement in the conspiracy of Amboise. Though the king of Navarre was allowed to go "at his liberty," he was, for all intents and purposes, also held "tanquam captivus" at court. ${ }^{161}$ Despite the general opinion that the "House of Guise would do all in its power to unite with the king of Navarre" in the event of François II's death, the Queen mother found a willing ally in the form of the king of Navarre when Charles IX ascended to the throne. ${ }^{162}$ As such, in March 1561, Catherine appointed Antoine to the post of lieutenant-general,

\footnotetext{
${ }^{160}$ Sir Nicholas Throckmorton to Queen Elizabeth I of England, 24 June 1560, CSP, Foreign 3: 143.

${ }^{161}$ Throckmorton to Elizabeth I of England, 17 November 1560, CSP, Foreign 3: 394; Throckmorton to Sir Robert Dudley, 17 November 1560, CSP, Foreign 3: 398.

${ }^{162}$ Suriano to the Doge of Venice, 3 December 1560, Despatches, 6.
} 
a position previously held by the duke of Guise, effectively giving the king of Navarre control over all of France's military forces. In spite of having conferred this enormous responsibility on the Bourbon prince, Catherine remained adamant that primary authority within the government still rested with her. ${ }^{163}$ However, unfortunately for Catherine, the king of Navarre began to gravitate towards the fallen Guise faction as early as spring 1561, with both the Bourbon princes and the Guise brothers becoming "great friends."164

So, how did Navarre's break with the Queen mother, as well as his subsequent alliance with the Guise come about? Despite their initial political amity during the first months of Charles IX's reign, there was probably always a sense of mutual mistrust and resentment between the Queen mother and the king of Navarre, particularly on Antoine's part, that had its origins during the reign of Henri II. In 1559, Françoise de Rohan, a female relative of the king of Navarre, began proceedings against Jacques de Savoie, duke of Nemours, a Guise ally at court, claiming not only that Nemours was the father of her illegitimate child, but also that the duke had secretly married her. ${ }^{165}$ When Nemours denied having ever married Françoise and likewise declared that he had no intention of marrying her, the king and queen of Navarre took the side of their female relative. ${ }^{166}$ Though Catherine attempted to appease both sides in this incident, she would eventually intervene on the side of Jacques, most likely acquiring the ire of the king of Navarre, who saw this whole affair as a matter of family honor. ${ }^{167}$

The rift between the Queen mother and her lieutenant-general, despite Antoine's continued prominent and comparatively influential station within Catherine's government, would

\footnotetext{
${ }^{163}$ Catherine de' Medici to Limoges, 27 March 1561, LCM 1: 176-7.

164 Thomas Windebank to Cecil, 19 June 1561, CSP, Foreign 4: 149.

${ }^{165}$ Matthew A. Vester, Jacques de Savoie-Nemours: L'apanage du Genevois au cour de la puissance dynastique savoyarde au XVIe siècle, trans. Eléonore Mazel and Déborah Engel (Genève: Droz, 2008), 67.

${ }^{166}$ Ibid., 74, 76.

${ }^{167}$ Ibid., 89-91,
} 
also come about largely as a consequence of the Guises' keen ability to manipulate the politically inept and overly ambitious Antoine. As previously mentioned, during his time at Catherine's court, Antoine de Bourbon was consumed by his desire to regain Spanish-occupied Navarre from King Philip, a fact that was not lost on the ever perceptive Guise brothers who tried to convince the king of Navarre that the best way to recoup the southern portion of his kingdom was to dislodge Catherine and assume her powers of governance. ${ }^{168}$

Another sore point between Catherine and the king of Navarre, to which the Guise clan contributed, was Antoine's frequent alignment with the political and religious program of the "triumvirate" and its allies at court. Comprised of the duke of Guise, the constable Montmorency, and Jacques d'Albon, the marshal Saint André, the triumvirate was essentially a noble coalition bent on suppressing the Protestant religion in France. ${ }^{169}$ Despite Antoine's initial Calvinist leanings, it seems that after falling under the influence of both the Guise brothers and the Cardinal of Ferrara, "le Roy de Navarre... s'est declaré pour la Party Catholique en faveur duquel il a conclu tout ouvertement." ${ }^{\prime 10}$ Regardless of Catherine's later reputation for Catholic fanaticism, the Queen mother, at least during the early years of Charles IX's reign, took a more moderate stance concerning the issue of religious heresy, tolerating it among her courtiers and even attending Calvinist services occasionally. As a result, the Queen mother was often accused by her more staunchly Catholic nobles and prelates of being too soft on heresy. In addition to the three members of the triumvirate, this backlash against Calvinism, and subsequently Catherine's

\footnotetext{
${ }^{168}$ Catherine de' Medici to Élisabeth de Valois, Queen of Spain, 22 March 1562, LCM 1: 591.

${ }^{169}$ Throckmorton to Cecil, 24 June 1562, CSP, Foreign, 5: 126.

${ }^{170}$ Throckmorton to Elizabeth I of England, 16 February 1562, CSP, Foreign, 4: 525; Ippolito d'Este, Cardinal of Ferrara to Cardinal of Borromée, 17 January 1562, in Négociations ou lettres d'affaires ecclesiastiques et politiques écrites au pape Pie IV et au cardinal Borromée, depuis canonizé saint, par Hyppolite d'Est, cardinal de Ferrare, ed. Simeon Piget. (Paris: S. Piget, 1658). http://books.google.com/books? id=nYmTawgq BtgC \&printsec=frontco ver $\& d q=N \%$ C3\%A9gociations + ou + lettres $+\%$ C3\%A9crites $+a u+P a p e+P i e+I V+e t+$ au + Cardinal + Borrom $\%$ C3\%A9e \&source=bl\&ots=84buV5SCMG\&sig=Ch7_F5yZHB6pOdFIw9boWDwblv4\&hl=en\&ei=G_C6TYCh

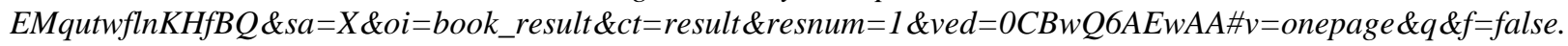


regency for tolerating it, was also encouraged by the Spanish ambassador, as well as by a “confederacy" of noble magnates devoted to Ippolito d'Este, cardinal of Ferrara. ${ }^{171}$

Fearing further loss of her own authority, Catherine initially solicited the king of Navarre to intercede on her behalf with Catholic noblemen, in an attempt to quell their disquietudes about her lenience towards Calvinism. However, it soon became evident that the king of Navarre was, at least for the moment, too easily swayed by the rabidly Catholic camp and too obsessed with regaining Spanish Navarre to help prop up her tottering regency. "The King of Navarre is all Spanish now," declared Sir Nicholas Throckmorton to William Cecil, and "men suspect that he will become a persecutor," since he now "only shows favor to the Papists."172 Though the Protestant Throckmorton's description of the king of Navarre's political and religious extremism may be slightly exaggerated, this assessment is nonetheless indicative of developing alliance between the King of Navarre and those ultra-Catholics that sought displace the Queen mother.

In reaction to this coalition forming against her, of which her lieutenant-general was a leading figure, Catherine, out of either political prudence or desperation, took "les voix des autres." ${ }^{173}$ The Queen mother now turned to Antoine's Protestant relatives, the Queen of Navarre and the prince of Condé, as well as other high-ranking Huguenot noblemen like the Admiral Coligny and his male relatives to help combat the triumvirate and its allies. ${ }^{174}$ Of course, another individual upon whom the Queen mother evidently called to rectify her political quagmire, was one of her young provincial ladies-in-waiting, Louise de La Béraudière, better known as the "belle Rouhet."

\footnotetext{
${ }^{171}$ Throckmorton to Cecil, 14 March 1562, CSP. Foreign, 4: 553; Throckmorton to Elizabeth I of England, 16 February 1562, CSP, Foreign 4: 525.

172 Throckmorton to Queen Elizabeth I of England, 9 March 1562, CSP, Foreign, 4: 552-3.

${ }^{173}$ Ippolito d'Este, Cardinal of Ferrara to Cardinal of Borromée, 17 January 1562, Négociations ou lettres écrites au Pape Pie IV et au Cardinal Borromée, 14.

${ }^{174}$ Throckmorton to Cecil, 14 March 1562, CSP. Foreign, 4: 553
} 
As previously mentioned, it is difficult to determine when Catherine placed her beautiful fille d'honneur before the king of Navarre, since very few primary sources mention Rouhet or her relationship with Antoine directly. In a letter dated May 1561, Antoine's would be religious mentor John Calvin scolds the king of Navarre for his numerous "folles amours" while residing at the French court. ${ }^{175}$ However, Antoine had always been a philanderer, so Rouhet may have not been involved in any of these dalliances that Calvin was mentioning in this written chastisement. Instead, it is more likely that the affair between the king of Navarre and Rouhet began only months before Antoine's death in November 1562, as nineteenth-century French historian Alphonse de Ruble has speculated. A scholar who depended heavily on primary sources, Ruble refers to a letter written by the Spanish ambassador, Perrenot de Chantonnay, dated May 23, 1562, as being the earliest allusion to the affair between Antoine de Bourbon and Mademoiselle Rouhet. ${ }^{176}$ Though it impossible to claim with certainty when their relationship began, Ruble's spring 1562 approximation seems like a reasonable conjecture due to what we know about the deteriorating relations between the Queen Mother and the king of Navarre during the early winter and spring of 1562. In other words, it seems that Catherine enlisted her pretty lady-inwaiting to seduce her lieutenant-general just as cordial interactions between the Queen mother and the King of Navarre were reaching their nadir.

Within the aforementioned Chantonnay letter, the Spanish ambassador dismayingly related how Rouhet was being used by the Queen mother to both to divulge secrets from Antoine, and to likewise detach the King of Navarre from his ultra-Catholic allies. ${ }^{177}$ In regards

\footnotetext{
175 John Calvin to Antoine de Bourbon, King of Navarre, May 1561, Lettres de Jean Calvin: Recueillies pour la première fois et publiées d'après les manuscrits originaux. ed. Jules Bonnet (Paris: Librairie de Ch. Meyrueis et Compagne, 1854), 400.

${ }^{176}$ Alphonse de Ruble, Antoine de Bourbon et Jeanne d'Albret : suite du mariage de Jeanne d'Albret. vol.4. (Paris: A. Labitte, 1886), 235.

${ }^{177}$ Chantonnay, 23 May 1562, quoted in Ruble, Antoine de Bourbon et Jeanne d'Albret, vol. 4, 235.
} 
to her first assignment, it is almost impossible to assess Rouhet's ability to, in the words of Chantonnay, "scavoir [les] secrets"” of the king of Navarre. As already implied, there is no surviving evidence that relates or suggests what information the "belle Rouhet" may have passed on to Catherine. There is also no evidence of any Catholic plots being foiled by the Queen mother that could have been conceivably brought to her attention by Rouhet. Yet, as for Rouhet's second mission, which was to drive a wedge between the king of Navarre and the confederacy of court Catholics, there is some indication that Catherine's young fille d'honneur may have had some success. Beginning in late spring and early summer of 1562 , it seems that the king of Navarre, though still allied with the ultra-Catholics at court, began to function less as a creature of the Spanish-Guise faction and began to represent the interests of Catherine's government more openly.

After the massacre at Vassy in March 1562, when the duke of Guise and his soldiers killed upwards of one-hundred Huguenot parishioners, the prince of Condé, Antoine's brother and now the head of the Huguenot movement in France, mobilized a Protestant army and took the city of Orleans on the pretext that King Charles and the Queen mother were being held captive there in the castle of Fontainebleau. ${ }^{178}$ Probably due to pressure from the Guise and their allies, the king of Navarre initially thwarted Catherine's attempts at negotiating with Condé, most likely because these ultra-Catholics at court initially feared that the Queen mother would tryto aid Condé and his party. ${ }^{179}$ However, by late April, Antoine would acquiesce to Catherine's request that both he and the Queen mother go to meet Condé, only to have this project denied by

\footnotetext{
${ }^{178}$ Estienne Pasquier, Lettres Historique: Pour les années 1556-1594. ed. D. Thickett (Geneva: Libraire Droz, 1966), 98.

${ }^{179}$ Throckmorton to Elizabeth I of England, 10 April 1562, CSP, Foreign 4: 597; Throckmorton to Cecil, 24 April 1562, CSP, Foreign 4: 624
} 
Guise, Montmorency and St. Andre. ${ }^{180}$ Later attempts by the Queen mother and the King of Navarre at negotiating with Condé and his Protestant allies in the summer of 1562 were more successful. Though they did little in way of compelling Condé to disarm, Catherine and Antoine worked furiously in conjunction with one another to achieve an accord with Condé, and the Queen mother's letters from that period indicate that she was now primarily depending on the king of Navarre to assuage this crisis with his brother. ${ }^{181}$ Writing to Rennes at the Imperial court in July 1562, Catherine explained to her ambassador that she was depending on Navarre to “renoué ce négoce avec mon cousin le prince de Condé...qu'il me prioyt ne plaindre poinct ma peine d'aller encores faire ung voyaige jusques au delà d'Orléans. ${ }^{182}$ The Queen mother expressed these same sentiments in a missive to the Charles de Cossé, the marshal Brissac, telling Brissac that it was the king of Navarre was working to pacify these troubles. ${ }^{183}$

Despite the King of Navarre's frequent implorations to his brother, the prince of Condé remained "obstinate" and continued to wage war on the royalist Catholic forces until his capture at Dreux in December 1562, by none other than the forces of the duke of Guise. ${ }^{184}$ As for Condé's brother, the king of Navarre was shot in the shoulder by an arabesque in October 1562 while attempting to combat French Huguenot forces in Normandy. ${ }^{185}$ Though it initially seemed that the king of Navarre would survive his injuries (Antoine even invited Mademoiselle de Rouhet to his bedside to accompany him in his convalescence), his wounds would become infected and the king of Navarre would die a month later. ${ }^{186}$ However, before succumbing to his injuries, Antoine de Bourbon reconverted and died in the "Confession of Augsburg," evidently

\footnotetext{
${ }^{180}$ Throckmorton to Elizabeth I of England, 27 April 1562, CSP, Foreign 4: 634.

${ }^{181}$ Henry Middlemore to Throckmorton, 23 June 1562, CSP, Foreign 5: 115.

${ }^{182}$ Catherine de' Medici to Rennes, 11 July 1562, LCM 1: 350.

${ }^{183}$ Catherine de' Medici to Charles de Cossé, marshal de Brissac, 11 July 1562, LCM 1: 351.

${ }^{184}$ Cecil, 17 July 1562, CSP, Foreign 5: 166.

${ }^{185}$ Smith to Cecil, 18 October 1562, CSP, Foreign 5: 375;

${ }^{186}$ Roelker, Queen of Navarre, 199.
} 
declaring in his delirium that if he survived, he would make peace with his brother and would do all in his power to further the Protestant cause within France. ${ }^{187}$ According to the Venetian ambassador, Marc Antonio Barbaro, Catherine seemed saddened by the king of Navarre's passing, and spoke of his death to the ambassador with "much grief." 188 However, a few days later, Barbaro wrote to the Venetian Senate, claiming that the "effect of the death of the King of Navarre remained to be seen," and that the Queen mother was meanwhile busy arranging a conference with the imprisoned Condé. ${ }^{189}$

\section{Charlotte de Beaune Semblançay, Baroness of Sauve}

Despite the eventual notoriety of Rouhet's affair with the two Bourbon princes, it is Charlotte de Beaune Semblançay, Baroness of Sauve, who is undeniably the most recognizable member of the "flying squadron," due to Marguerite de Valois's extensive and generally unflattering depiction of Madame de Sauve in her memoirs, as well as to Sauve's reputation for being "l'une des plus belles de la cour d'Henri III, \& de celles de deux rois ses prédécesseurs."190 Madame de Sauve was of a slightly higher pedigree than Rouhet and Limeuil. She was the daughter and heiress of the Touraine nobleman Jacques de Beaune, baron Semblançay and Viscount of Tours, and upon his death, the young Charlotte assumed her father's titles. Spending much of her early life at court, in 1569, Charlotte would marry Simon Fizes, baron de Sauve, a prominent secretary of State during the reigns of Charles IX and Henri III. Though Emmanuel le Roy Ladurie had asserted that Fizes was a Guise protégé, scholar N.M Sutherland has also

\footnotetext{
${ }^{187}$ Marc Antoinio Barbaro to the Venetian Senate, 25 November 1561, Despatches, 65; Barbaro to the Venetian Senate, 14 December 1562, Despatches, 69.

${ }^{188}$ Barbaro to the Doge of Venice, 21 November 1562, Despatches, 64.

${ }^{189}$ Barbaro to the Venetian Senate, 25 November 1562, Despatches, 65.

${ }^{190}$ Jean-François Dreux du Radier, Mémoires historiques, critiques, et anecdotes des reines et régentes de France. (Paris, 1808), 393; Marguerite de Valois, Memoirs, 58.
} 
claimed that Fizes political ascent, starting from the position of garde de sceaux in 1553 and culminating in his appointment as secretary of State in in 1567 , can be attributed to the sponsorship of the Queen mother. ${ }^{191}$ It is therefore due to a sense of indebtedness, or more likely the desire to acquire additional patronage, that Fizes tolerated or even encouraged the entrance of his wife into numerous affairs on behalf of Catherine de' Medici.

Though Madame de Sauve was reputed to have had numerous dalliances while acting as one of Catherine's dame d'honneurs, these affairs were not always at the behest of the Queen mother. This section will focus on two of the most notable lovers whom the baroness was solicited to seduce as a member of Catherine's "flying squadron," Henri de Bourbon, King of Navarre and François de Valois, Duke of Alençon. With Marguerite de Valois's rather colorful depiction of the tumultuous love triangle between the king of Navarre, the duke of Alençon, and Madame de Sauve in her memoirs, we are given a detailed analysis of the methods used by Sauve to manipulate these men, as well as the political reasoning behind these liaisons.

Regardless of eventual conjectures that could be made about the affair between Madame de Sauve and the Duke of Guise, we can conclude with almost absolute certainty that Catherine de' Medici used the beautiful baroness to seduce both her youngest son, the duke of Alençon and her son-in-law, the king of Navarre, in an attempt both to quash their budding alliance and to immobilize them politically in the months following the St. Bartholomew’s Day Massacre. ${ }^{192}$ Though the duke of Alençon remained a staunch Catholic until his premature death in 1584, beginning in around 1571, Catherine's youngest son began to assume a much more moderate

\footnotetext{
${ }^{191}$ Emmanuel Roy Ladurie, The Peasants of Languedoc (Champaign, IL: University of Illinois Press, 1977), 178-9; N.M. Sutherland, The French Secretaries of State in the Age of Catherine de Medici (London: University of London, the Athlone Press, 1962), 160.

192 Marguerite de Valois, Memoirs, 48.
} 
stance on the issue of religious heresy. ${ }^{193}$ When Coligny returned to the Valois court after the conclusion of the Third Religious War, the Calvinist admiral became a kind of mentor figure to the youngest and decidedly most neglected of Catherine's sons, much to the chagrin of both the Queen mother and Alençon's two elder brothers. ${ }^{194}$

Why Alençon formed this friendship with Coligny and subsequently came to head the religious moderate, or politique, movement within France, can never be fully understood. Yet, one can still speculate as to his motivations. Childhood illness had left the young Alençon poxfaced and ill-formed, and the personal insecurities that accompany such physical deformities, coupled with both the inattention the duke received from his mother and the hatred he bore for his brothers, undoubtedly played a role in his decision to befriend the Admiral and then the king of Navarre. However, it was most likely his intense personal ambition that was left unfulfilled due to both his age and intellectual inadequacies that led Alençon to politically and militarily align with the Huguenot cause around the time of the massacre. In short, by collaborating with his family's religious rivals, the duke hoped to gain the political influence and he had long craved but had thus far been denied by his mother and brothers.

As for Alençon's would be political ally, Henri de Bourbon, King of Navarre, his decision to form an alliance with Catherine's youngest son came about less the result of political ambition and more due to his desire to be free of the Valois captors. Immediately following the St. Bartholomew's Day Massacre in August 1572, the Huguenot king of Navarre, along with his cousin Henri I de Bourbon, prince of Condé were kept confined at the Valois court, and compelled to convert to "l'église Catholique, Apostolique [et] Romaine."195 However, the

\footnotetext{
${ }^{193}$ Holt, The Duke of Anjou, 23.

${ }^{194}$ Jacques-Auguste de Thou, Histoire Universelle de Jacques-Auguste de Thou: Depuis 1543 jusqu'en 1607 (London, 1734), vol. 6: 279.

${ }^{195}$ De Thou, Histoire Universelle 6: 439.
} 
conversion of the king of Navarre did little to assuage Catherine's and her Catholic courtiers' fears that the king of Navarre's and his conspirators, which now included the duke of Alençon, were secretly scheming for Navarre's release, so that the king may rejoin his religious allies and take military action against the crown.

Needless to say, these fears concerning both Navarre and Alençon were not unfounded. According to Marguerite de Valois, her younger brother, the Duke of Alençon, had been aligned with the Huguenot party even before the St. Bartholomew's Day Massacre, when those French Huguenots, most likely Coligny, who favored war against Spain, had made promises to Alençon, assuring him the crown of the Netherlands should France support Dutch independence. ${ }^{196}$ Therefore, it is not surprising that after assassination of the Admiral, both Alençon and the king of Navarre made written promises to the Huguenots that they would avenge the death of Coligny. When the aging Montmorency withdrew from court in 1574, duke of Alençon became the main focal point for those disgruntled Protestants and politique Catholics. However, despite his increasing influence within politique circles at court, the young duke still failed to receive highranking appointments within Charles IX's government. Though he had been promised the post of lieutenant-general by his brother, the position ultimately went to his archrival, the ultra-Catholic Henri de Lorraine, duke of Guise, and perhaps it was this stinging betrayal that caused Alençon to conspire against his brother in February 1574. In addition to making plans with the King of Navarre to escape the French court, it seems that Alençon and his Protestant allies were attempting to coordinate a series of Huguenot uprisings that would result in a coup at court. ${ }^{197}$ When questioned about the plot by King Charles and the Queen mother, Alençon claimed that his actions were not aimed at his brother, but rather at dislodging the duke of Guise, and later in

\footnotetext{
${ }^{196}$ Marguerite de Valois, Memoirs, 44.

${ }^{197}$ Holt, The Duke of Anjou, 38.
} 
a written declaration, the King of Navarre would disavow any knowledge of the plot. ${ }^{198}$ As for Catherine's reaction to her son's perfidies, it seems that due to political necessity she was inclined to support the amicable rapprochement between King Charles and Alençon after the plot had been exposed, but was insistent that Alençon's lower-ranking conspirators "be punished."199

Prior to the exposure of this intended coup d'état, Catherine had been well aware of the "mescontentment du duc d'Alençon de la journee de St. Barthelemy," and despite Alençon's later rebellious endeavors, Catherine did initially make attempts to mitigate her son's dissatisfaction with his relegated position within his brother's government. For instance, the Queen mother put her youngest son in charge of Catholic army bent on retaking the Protestant stronghold of La Rochelle in $1573 .{ }^{200}$ However, it seems that by the commencement of Henri III's reign, Catherine had decided to employ a new tactic to assuage her son's discontentment, and to likewise obstruct the troublesome alliance between Alençon and king of Navarre.

As previously stated, there are no sources that unassailably prove that Catherine gave direct orders to Charlotte de Sauve, or to any other member of the "escadron volant," to seduce these two princes for Catherine's benefit. In fact, within her memoirs, Marguerite de Valois asserts that it was the mignon Louis Berenger du Guast, in conjunction with Henri III, who solicited the beautiful baroness to seduce Alençon and Navarre. ${ }^{201}$ However, considering the political ramifications of these simultaneous affairs, as well as the strong patron-client ties existing between the Queen mother and both Charlotte's Fizes and Beaune relations, it seems much more likely that Catherine was the one who initiated, or at the very least guaranteed, its occurrence.

\footnotetext{
198 Dr. Valentine Dale, 24 March 1574, CSP, Foreign 10: 483.

${ }^{199}$ Dale to Burghley (Cecil), 22 April 1574, CSP, Foreign 10: 491.

${ }^{200}$ Michel de la Hugueyre, Mémoires inédites de Michel de la Hugueyre (Paris: Libraire Renouard, 1877), 169.

${ }^{201}$ Marguerite de Valois, Memoirs, 48.
} 
In addition to being the wife of one of Catherine's secretaries of State, whose career Catherine had personally nurtured, Madame de Sauve was also the niece of Claude de Beaune, duchess of Rouannez, a great favorite of the Queen mother since the reign of Henri II, and who had for some time acted as the treasurer of Catherine's household. ${ }^{202}$ It was Claude's close rapport with the Queen mother that caused Claude's second husband, the marquis of Boisi, to be elevated to the duchy of Rouannez upon his marriage with Claude. Also due to Claude's friendship with Catherine, the royal favorite was able to secure the archbishopric of Bourges for her brother Renaud de Beaune. ${ }^{203}$ Though Claude probably had no role in the fruition of the affair itself, it is likely that Claude's friendship Queen mother recommended the services of the young Charlotte to Catherine, facilitating Charlotte's entrance into the Queen's household and likewise into Catherine's female-oriented political system.

Another indication of Catherine's complicity in these affairs is the simple fact that Madame de Sauve was one Catherine's dame d'honneurs, meaning that the young baroness's daily activities usually revolved around Catherine's own schedule. As for Marguerite's fingering of Du Guast as the primary culprit behind Madame de Sauve's dalliances, it is likely that Marguerite misrepresented this admission in her memoirs due to political caution. Both Henri III and Catherine were alive while Marguerite was penning her memoirs in the chateau d'Usson where she was confined. Therefore, Marguerite may have been reluctant to attribute primary responsibility to her brother and mother in this sordid affair while they still had the power to release her.

\footnotetext{
${ }^{202}$ Sutherland, French Secrétaires, 160 ; Brantôme, Oeuvres complètes, 7: 387 ; De Thou, Histoire Universelle 3: 511; Cloulas, Catherine de' Médicis, 191.

${ }^{203}$ Pierre Bayle. Dictionnaire historique et critique de Pierre Bayle, ed. by Jaques George de Chaufepié et al. (Paris: Desoer, 1820.) 13, n. 70. http://books.google.com/books?id=D2V6QT2H4JIC\&pg=PA448\&dq=Dictionnai re+historique+et+critique+de+Pierre+Bayle+volume+13+1820\&hl=en\&ei=Oou3TZqSAuTv0gGa_O3WDw\&sa=\& oi=book_result\&ct=book-thumbnail\&resnum=2\&ved=0CDEQ6wEwAQ\#v=onepage \&q=renaud\%20de $\% 20 \mathrm{beau}$ ne \& $\mathrm{f}=$ false. Within this particular footnote, the editors mistakingly refer to Claude de Beaune as "Marguerite de Beaune."
} 
In addition to the aforementioned factual distortion in Marguerite's writings, another weakness Margeruite's account is that she fails to provide dates for when these events that she depicted actually occurred. However, regardless of this deficiency, we are still able to roughly estimate when Charlotte de Sauve was enlisted by Catherine, Henri III and Du Guast to seduce the king of Navarre and the duke of Alençon. The evidence seems to indicate that this affair commenced in either January or February of 1575. In a letter to Sir Francis Walsingham dated February 13, 1575, Dr. Dale recounted that there was a continued state of jealousy existing between the King of Navarre and Alençon that was "not yet quenched." 204 This missive is then followed by another letter from Dr. Dale in March of the same year, in which he explained to Cecil that dissention was being sown "between Monsieur and the King of Navarre by a women," in an obvious reference to Madame de Sauve. However, rather than attributing quarrel to the machinations of Catherine, Henri III or Du Guast, Dale mistakenly claims that it was the duke of Guise who incited this jealousy between Alençon and Navarre. ${ }^{205}$

Despite her account's evident faults, Marguerite's memoirs are, nonetheless, the most extensive depiction of the love-triangle between the Madame de Sauve, the duke of Alençon and the King of Navarre, and give the most complete case study in how the Queen mother used a member "flying squadron" to manipulate domestic politics and destabilize rival court factions. According to Marguerite, Henri III and Du Guast, and we can assume Catherine, recognized the threat that an alliance between Alençon and Navarre posed to the stability of the realm, and therefore sought to initiate a quarrel between the two young men over the beautiful Madame de Sauve, whom both Alençon and Navarre "visited." Regardless of the relative simplicity of the

\footnotetext{
${ }^{204}$ Dale to Walsingham, 13 February 1575, in Calendar of State Papers: Foreign Series, of the Reign of Elizabeth, preserved in the Public Record Office, ed. Allan James Crosby (London: Public Record Office, 1880) vol. 11, doc. 24. British History Online, http://www.british-history.ac.uk/report.aspx?compid=73211.

${ }^{205}$ Dale to Burghley (Cecil), 18 March 1575, CSP, Foreign, BHO 11: doc. 51.
} 
plot, Marguerite claims that baroness's concurrent liaisons caused much "disquietude and unhappiness" between Alençon and Navarre, and well as between the two princes and Marguerite, who was considered to be the bond that united the two men. ${ }^{206}$

Of course, it was well known that Madame de Sauve had numerous other lovers, including the duke of Guise, Du Guast and Gilles de Souvré, the marquis de Courtenvaux. Still, as Marguerite recounted, "the passion which these two young men had conceived" for Catherine's dame d'honneur would eventually become "so violent that ambition and every obligation of duty were at once absorbed by their attentions to this woman." 207 Though they make no mention of interference of Madame de Sauve, or any lady for that matter, the missives sent to Sir Francis Walsingham by English envoys Sir John Willes and Dr. Valentine Dale support Marguerite's depiction of the severity of this schism and the success of Madame de Sauve's maneuvering on behalf of the Queen mother, Henri III, and his mignon. "The quarrel between the King of Navarre and the Duke is greater than ever it was," announced Willes, "so that one of these days they will cut the throats one of the other."208 Dr. Valentine Dale also echoed Willes' observations in another letter to Walsingham, stating that the king of Navarre was still "set agog to make himself party against Monsieur.,"209

However, in addition to causing a rupture between the duke of Alençon and the king of Navarre, Catherine and Henri III also sought to create discord between Marguerite and the two besotted princes, since Marguerite was attempting to act as a mediator between her husband and brother. ${ }^{210}$ According to Marguerite that "Circe," as the Queen of Navarre so indignantly referred

\footnotetext{
${ }^{206}$ Marguerite de Valois, Memoirs, 48.

${ }^{207}$ Marguerite de Valois, Memoirs, 48.

${ }^{208}$ Sir John Willes to Walsingham, 13 June 1575, CSP, Foreign, BHO 11: doc. 176.

${ }^{209}$ Dale to Walsingham, 13 June 1575, CSP, Foreign, BHO 11: doc. 177.

${ }^{210}$ Vincent J. Pitts, Henri IV of France: His Reign and Age (Baltimore, MD: The John Hopkins University Press, 2009), 72.
} 
to Madame de Sauve, went to Marguerite's husband, claiming that Marguerite was in fact jealous of her, and that Marguerite had recently taken sides with her brother, now Navarre's political as well as romantic rival, the duke of Alençon. Madame de Sauve further claimed that Marguerite could so often be found in Alençon's apartments because Marguerite was having an affair with a member of her brother's entourage, Bussy d'Amboise. ${ }^{211}$ Although in her memoirs Marguerite asserted that the King of Navarre "could not be induced to lend an ear to the story," in July 1575 the English ambassador nonetheless recounted that Bussy d'Amboise was forced to flee court for fear of the king of Navarre's vengeance. ${ }^{212}$ Having lost both her husband's confidence and favor, Marguerite turned her attention to separating her brother from Madame de Sauve, but, like Marguerite's husband, the duke of Alençon was incontrovertibly besotted by Catherine's maid of honor. $^{213}$

Of course, there were factors that could have contributed to this schism between the duke of Alençon and the king of Navarre. In addition to any resentment Alençon may have felt at the predictions made that he would never rule, and that Navarre would "have his portion," it seems that both men coveted the office of lieutenant general, and there may have been some rivalries between members of their respective entourages that would have exacerbated their own feud. ${ }^{214}$ However, though these issues may have had some role in creating this rift between Catherine's youngest son and son-in-law, they do not plausibly account for why the relationship between Alençon and Navarre and Marguerite and the two men seemed to deteriorate simultaneously and so severely. Therefore, it can only be assumed that it was Madame de Sauve's interference that played that was the primary cause of this quarrel.

\footnotetext{
${ }^{211}$ Marguerite de Valois, Memoirs, 58-60.

${ }^{212}$ Dale to Burghley (Cecil), 6 July 1575, CSP, Foreign, BHO 11: doc. 210; Marguerite de Valois, Memoirs, 60.

213 Ibid., 59.

${ }^{214}$ Pitts, Henri IV of France, 72.
} 
In the end, despite her best efforts, it seems that the estimable charms of Madame de Sauve could not squash the independent ambitions of the duke of Alençon and the king of Navarre. With the aid of Marguerite, the duke of Alençon was the first to escape from court in September 1575 , and was followed in his flight by the king of Navarre in early $1576 .{ }^{215}$ Having finally been separated from Madame de Sauve, and now surrounded by his friends and dependents in Gascony, the king of Navarre apparently emerged from his political lethargy, and finally conceived of the "plot and machinations of [his] enemies." Though the duke of Alençon was at that time residing in Champagne, Marguerite asserts that a state of friendship nonetheless now existed between the two former romantic rivals. ${ }^{216}$

Despite the flight of Madame de Sauve's two royal lovers, the pretty baroness still appears to have remained a visible and prominent fixture at court and a key component within Catherine's network of court noblemen, as shown in the May 15, 1577 entry of Pierre de l'Estoile's journal. After the sacking of La Charité, Henri III hosted a lavish banquet with his brother, now of the duke of Anjou, and with many other high-ranking lords and ladies in attendance. According to l'Estoile, “en ce beau banquet, les dames les plus belles et honnêtes de la cour, étant à moitié nues et ayant leurs cheveux épars comme épousées, furent employées à faire le service." Evidently, during these festivities, Madame de Sauve acted as one of the maitresses d'hôtel. ${ }^{217}$ As to whether or not Henri III and Catherine were attempting to once again reignite the newly returned Anjou's passions for the baroness by giving her this prominent position within the festivities, we can only guess. However, it is interesting to note that when Catherine's “prodigal son” finally returned to Paris in February 1584, this time after Anjou's

\footnotetext{
${ }^{215}$ Catherine de' Medici to Emmanuel Philibert, Duke of Savoy, 15 September 1575, LCM 5: 132; Marguerite de Valois, Memoirs, 68.

${ }^{216}$ Marguerite de Valois, Memoirs, 76-7.

${ }^{217}$ L'Estoile, 15 May 1577, Journal, 145-6.
} 
disastrous military campaign in the Netherlands, Anjou's newfound amity with his brother the king seems to have been accompanied by, according to l'Estoile, a renewed romantic interest in Madame de Sauve. ${ }^{218}$

As previously mentioned, the main factor that caused these noblewomen to acquiesce to the requests of the Queen mother was the prospect of patronage and economic advancement. So, what did Louise de La Béraudière, or "la belle Rouhet" and Charlotte de Sauve hope to gain, or eventually acquire, from seducing these princely magnates on behalf of the Queen mother?

Though Catherine undoubtedly initiated, or at least encouraged these liaisons, existing evidence seems to indicate that as the affairs were occurring, it was the royal lovers themselves, not Catherine, who distributed forms of patronage to Rouhet's and Sauve's male relatives. For instance, Rouhet's uncle François du Fou, seigneur du Vigean, had a high-ranking position within the Antoine de Bourbon's household during the king of Navarre's liaison with his niece. ${ }^{219}$ As for Charlotte de Sauve, her uncle Renaud de Beanue was the duke of Anjou's chancellor until 1580, and as a result of Renaud's chancellorship, another of Charlotte's uncles, Martin de Beaune, was given the position of premier conseiller de Monseigneur in $1576 .{ }^{220}$

If Catherine made any guarantees to Mademoiselle de Rouhet or Madame de Sauve before lobbying them to ensnare these three male royals, it was either the false promise of marriage, most likely in the case of Rouhet, or the assurance that these women would be financially taken care of after their respective affairs had ended. Though there is no evidence that implicitly states that Rouhet was promised marriage to the king of Navarre by either Antoine himself or the Queen mother, it seems that after the death of the king of Navarre, Rouhet thought

\footnotetext{
${ }^{218}$ Holt, The Duke of Anjou, 203; L'Estoile, Journal, 21 February 1584, 351.

${ }^{219}$ Ruble, Antoine de Bourbon et Jeanne d'Albret, 251.

${ }^{220}$ Mack P. Holt, "Patterns of Clientele and Economic Opportunity at Court During the French Wars of Religion: The Household of François, Duke of Anjou," French Historical Studies 13, 3 (Spring 1984): 316-17.
} 
of herself as if she were the dead king's widow. As Antoine's brother, the prince of Condé, sardonically recounted in his memoirs, Mademoiselle de Rouhet wore the "vestements de dueil qu'elle a naguéres porté pour les decez de celuy qu'elle avoit infatué, le plus grand qui fut à la suytte du Roy.",221

However, a much more likely promise made by Catherine to Rouhet, and likewise to Madame de Sauve, was that the crown would secure a comparatively advantageous marriage for her should the affair end or Antoine decide not to take care of her financially. If that were the case, Catherine did indeed fulfill that obligation. After the death of Navarre, Rouhet would quickly be married to Louis de Madaillan, seigneur de Lesparre and baron d'Estissac, who, among other appointments, was also the governor of La Rochelle. ${ }^{222}$ In January 1580, fifteen years following the death of her first husband, Rouhet would then marry Henri III's future premier maître d'hôtel, Robert de Combaut, seigneur de Arcis-sur-Aube, and around the time of his marriage to Rouhet, Combaut would acquire the title 'comte de Chateauvillain'. ${ }^{223}$

As for Madame de Sauve, it is unlikely that she had any allusions about marriage between herself and either the duke of Alençon or the king of Navarre. Knowing the blind passion that the young baroness incited in her youngest son and son-in-law, the Queen mother certainly would not have planted that idea her lady's head. Therefore, due also to the fact that Sauve's was already married to a trusted secretary of the Queen, Madame de Sauve most likely hoped simply that this affair would improve her position at court and ensure her good standing with the Queen mother. Madame de Sauve's husband, Simon de Fizes, died in 1579, and though

\footnotetext{
${ }^{221}$ Louis de Bourbon, prince of Condé, Mémoires de Condé : servant d'éclaircissement et de preuves à l'histoire de M. de Thou ed. Denis-François Secousse and Nicolas Lenglet Dufresnoy Bourbon (London, se vend à Paris, Chez Rollin, fils, 1743.), vol. 4: 628. Eighteenth Century Collections Online. http://find.galegroup.com/ecco/infomark . do $? \&$ contentSet=ECCOArticles\&type $=$ multipage \&tabID=T001\&prodId=ECCO\&docId=CW108730310\&source $=$ gale \&userGroupName=wvu_main\&version $=1.0 \&$ docLevel=FASCIMILE.

${ }^{222}$ Brantôme, Oeuvres completes, n. 405.

${ }^{223}$ L'Estoile, January 1580, Journal, 241.
} 
she would continue to have numerous lovers, the still beautiful Charlotte married once again in 1584. This time, her husband was François de la Trémoille, marquis of Noirmoutier and a first cousin to the princess of Condé. Though it is difficult to discern whether the Queen mother had had a hand in this advantageous marriage, we do know that for the duration of Catherine's life, Charlotte's prominent position in the Queen's household continued, and after the succession of Henri IV, she remained one of the most visible noblewomen at court. 


\section{Conclusion}

The historiography concerning early modern female networks has developed over the past few decades, but has left some topics unexplored. One example is the political career of Catherine de' Medici, which has continued to be marked by the overly narrow, male-oriented focus of previous scholarship that concentrated on the Queen mother's political interactions with her sons and male courters. In response, this thesis has sought to bring greater attention to the existence of the often neglected topic of female political networks in relation to one of the most formidable female sovereigns in the course of European history, Catherine de' Medici.

Though Catherine started out as a relatively insignificant figure, neglected by her husband King Henri II and overshadowed by his beautiful mistress, the premature death of her husband unexpectedly propelled her into an unprecedented position of power for a female ruler in France during the early modern period. However, despite her status as Queen mother for three successive French kings, the degree to which Catherine was permitted to exercise her perceived maternal rights over her sons' governments remained perpetually in question. Following King Henri's death in 1559, rival family factions fought both Catherine and each other for the governance of the realm, primarily using discord over religion and the continued existence of heresy to discredit one another. Though the Queen mother and the crown had its allies, the Guise and Bourbon princes, the most powerful magnates in the realm (and who in theory should have safeguarded the interests of the crown), were ambitious and politically irresolute. They took every opportunity to pry more authority from the Queen mother and her minor sons.

In addition to those internal schisms caused by religious affiliations, court factionalism and personal ambition, Catherine also inherited a state that was both financially and militarily exhausted due to the decades-long Hapsburg-Valois wars. As the politically imposing Spanish 
king was calling for the elimination of Calvinism within France, France's other traditional enemy, the monarch of England, Queen Elizabeth I, was funneling money and men into the Huguenot cause, and on top of that, France's traditional ally against the English, the Scottish monarch, Mary Stuart, was member of the Guise clan.

It is not the intent of this thesis to minimize the importance of the role that Catherine's direct personal relationships with her sons and political interactions with her male noblemen had on her ability to govern France effectively. The point is to highlight the alternative, though decidedly not usual, methods that the Queen mother used to exercise her political influence, namely through the construction and utilization of a female political network comprised of both her female relatives and the lower-ranking noblewomen within her household. In addition to illustrating how Catherine sought to use both her female relatives and noble clients to help solidify and prolong her political authority, this thesis has also examined the degree to which her incorporation of these women proved useful to the Queen mother, and in some instances, what caused Catherine's attempted use of certain women to fail.

The first chapter showed that, despite Élisabeth de Valois' lack of male issue and premature death, Catherine was able to reap substantial benefits from her eldest daughter's affiliation with the most powerful monarch in Europe. While Philip was married to Élisabeth, the Spanish king was much more inclined to make overtures of friendship to the Queen mother's government, sending Habsburg troops to help defeat rebellious Huguenot armies and acting as an intermediary between the French crown and his male relatives, the Holy Roman Emperor and the king of Portugal. In her eldest daughter, Catherine likewise found a valuable ally who could positively represent not only French interests, but Catherine's personal political agenda at the Spanish court. Though Élisabeth was not always able to convince her Spanish husband to 
consent to Catherine's requests, even Philip affection's for Élisabeth had their limits, letters written by Catherine's ambassadors in Spain concerning the actions of Queen Élisabeth on behalf of the French crown indicate that Catherine's eldest, in almost every respect, was a useful and willing political instrument of Catherine's political goals.

Catherine hoped that Marguerite, like her older sister Élisabeth, would serve as a symbol of unity between the French crown and her husband's government, and would promote both the interests of the French crown and Catherine's personal objectives for her husband the King of Navarre. However, despite these similar purposes within Catherine's kinship-based political system, Marguerite was only a marginally effective member of Catherine's network. Though Marguerite's memoirs seems to indicate that the young queen of Navarre possessed a profound sense of respect and loyalty for her mother, Marguerite's reputation for sexual immorality and her foolish political and military ventures rendered her more a liability than an ally as her mother had initially hoped.

As indicated in the second chapter, another member of Catherine's network whose position proved comparatively unhelpful to Catherine was her daughter-in-law, Elisabeth of Austria. Though Elisabeth's Habsburg connections may have caused Catherine initially to mistrust her daughter-in-law, probably causing the Queen mother to miss some opportunities, it seems more likely that Elisabeth's lack of utility stemmed from other contributing influences, such as Elisabeth's reserved nature. Therefore, it must be remembered that issues such as individual temperament and intelligence, as well as the nature and strength of relationships within the network, likewise played an important role in determining political effectiveness of these women. 
Despite recent revisions in the historiography of Louise de Lorraine-Vaudémont, which portrays Louise's utility as a consort in a more positive light, the evidence incontrovertibly shows that the addition of Louise and her siblings within Catherine's political network likewise did more harm than good to the French crown. Though Catherine's and Henri III's intentions for Louise and her siblings, were, at least in theory, politically sound, the simultaneous membership of this group within the house of Lorraine-Guise prevented them from becoming wholly loyal to Catherine and her son. Due to its extensive political, economic, and clerical reach, members of the house of Lorraine had vast resources at their disposal, and therefore had little incentive to remain loyal to the crown if the Valois monarchy would not allow them to fulfill their political ambitions and follow their religious consciences.

Initially, Catherine faced similar difficulties in incorporating Mary Stuart, Queen of Scots into her political network, since Mary's Guise uncles both fostered a sense of animosity between their niece and the Queen mother, and because they provided an alternative outlet for political support, making the Queen of Scots less dependent on the goodwill of her former mother-in-law. Mary's eventual supplication to Catherine only came when the Queen of Scots found herself particularly reliant on the Queen mother to achieve her liberation from her captivity in England. Though the house of Lorraine had its own vast diplomatic network, the belligerently UltraCatholic Guise clan was in no position to negotiate with the Protestant Queen of England for the release of their royal female relative. For that, Mary needed the intervention of her more religiously circumspect and politically palatable former mother-in-law.

Shifting from the discussion of royal women to that of noblewomen, it seems that the primary rationale for both Mademoiselle de Rouhet and Madame de Sauve for entering into these liaisons at the behest of Catherine was to improve their standing both with the Queen mother and 
within the court in general. During the early modern period, one of the few mediums by which women could hope to obtain a "salaried position" and social and economic advancement, was through the noble and or royal household, and as previously mentioned, as Queen mother and regent, Catherine has an unprecedented degree of patronage powers for a woman. ${ }^{224}$ In summary, the female-oriented political network of Catherine de' Medici was a geographically vast, as well as politically and economically diverse, system of women accumulated by the Queen mother in the nearly three decades that she exercised political influence at the French court. Comprised of both her female relatives and the noblewomen residing at court, this system was simultaneously a kinship and patron-client network, whose members heeded Catherine's requests out of either personal loyalty or want of economic and political gain. Despite being previously marginalized within the narrative of the French Wars of Religion, due to both a lack of primary sources and the inclination of historians to focus on Catherine's tumultuous relationship with her sons and male noblemen, these women, nonetheless, played an important role in the course of French domestic and international political during the sixteenth century, and likewise helped build the reputation of one of the most extraordinary and formidable women in French history.

\footnotetext{
${ }^{224}$ Kettering, "Household Service," 56.
} 


\section{Bibliography}

\section{$\underline{\text { Primary Sources }}$}

Albret, Jeanne de. Jeanne d'Albret: Mémoires et Poésies. Edited by Alphonse de Ruble, Geneva: Slatkine Reprints, 1970.

Bourbon, Louis I de, prince de Condé. Mémoires de Condé: servant d'éclaircissement et de preuves à l'histoire de M. de Thou. Edited by Denis-François Secousse and Nicolas Lenglet Dufresnoy. Vol. 4. A London, se vend à Paris, Chez Rollin, fils, 1743. Eighteenth Century Collections Online. http://find.galegroup.com/ecco/infomark.do?\&contentSet=ECC OArticles \& type $=$ multipage $\&$ tabID $=$ T001 $\&$ prodId $=$ ECCO $\&$ docId $=C W 108730310 \&$ source $=$ gale \&userGroupName=wvu_main\&version=1.0\&docLevel=FASCIMILE.

Brantôme, Pierre de Bourdeille, seigneur de. Illustrious Dames of the Court of the Valois Kings. Translated by Katharine Prescott Wormaley. New York, NY: The Lamb Publishing Co., 1912.

Brantôme, Pierre de Bourdeille, seigneur de. Oeuvres complètes de Pierre de Bourdeille. Edited by Ludovic Lalanne. Vol. 10. Paris: Libraire Renouard, 1881.

Calendar of State Papers: Foreign Series, of the Reign of Elizabeth, preserved in the Public Record Office. Edited by Arthur John Butler et al. London: Public Record Office, 1863-1950.

Calendar of State Papers: Foreign Series, of the Reign of Elizabeth, preserved in the Public Record Office. Edited by Arthur John Butler et al. Vol. 11. London: Public Record Office, 18631950. British History Online. http://www.british-history.ac.uk/report.aspx?compid.

Calendar of State Papers relating to Scotland and Mary, Queen of Scots: 1547-1603. Edited by Joseph Bain et al. Edinburgh: H. M. General Register House, 1898-1969.

Calvin, Jean. Lettres de Jean Calvin: recueillies pour la première fois et publiées d'après les manuscrits originaux. Edited by Jules Bonnet. Vol. 1. Paris: Librairie de Ch. Meyrueis et Compagne, 1854.

De Thou, Jacques-Auguste. Histoire Universelle de Jacques-Auguste de Thou: Depuis 1543 jusqu'en 1607. Edited by Nicolas Rigault et al. Vol. 6. London, 1734.

Este, Hippolyte de. Négociations ou lettres d'affaires ecclesiastiques et politiques écrites au pape Pie IV et au cardinal Borromée, depuis canonizé saint, par Hyppolite d'Est, cardinal de Ferrare. Edited by Simeon Piget. (Paris: S. Piget, 1658). http://books.google.com/books?id=nYmTawgq $\mathrm{BtgC} \&$ printsec $=$ frontcover $\& \mathrm{dq}=\mathrm{N} \% \mathrm{C} 3 \% \mathrm{~A} 9 \mathrm{gociations}+\mathrm{ou}+$ lettres $+\% \mathrm{C} 3 \% \mathrm{~A} 9 \mathrm{crites}+\mathrm{au}+$ Pape+Pie+IV+et+au+Cardinal+Borrom\%C3\%A9e\&source=bl\&ots=84buV5SCMG\&sig=Ch7_F 5yZHB6p0dFIw9boWDwblv4\&hl=en\&ei=G_C6TYChEMqutwflnKHfBQ\&sa=X\&oi=book_res ult\&ct=result\&resnum=1\&ved=0CBwQ6AEwAA\#v=onepage $\& q \& \mathrm{f}=$ false . 
Henri III. Lettres de Henri III: Roi de France. Edited by Pierre Champion and Michel François. Paris: C. Klincksieck 1959.

La Hugueyre, Michel de. Mémoires inédites de Michel de la Hugueyre: publiés d'après les manuscrits autographes pour la Sociéte de l'histoire de France par le baron A. de Ruble. Edited by Alphonse de Ruble. Paris: Renouard 1877.

L'Estoile, Pierre de, Journal pour le règne de Henri III (1574-1589). Edited by L.-R. Lefèvre. Paris: Gallimard, 1943.

La Mère des Guises: Antoinette de Bourbon, 1494-1583. Edited by Gabriel de Pimodan. Paris: Edouard Champion, 1925.

La Mothe Fénélon, Bertrand de Salignac, sieur de. Correspondance Diplomatique de Bertrand de Salignac de la Mothe Fenelon : Ambassadeur de France Angleterre de 1568-1575. Edited by Jean Baptiste Alexandre Théodore Teulet and Charles Purton Cooper. Vol 1. Paris and London: Béthune et Plon, 1838-1840.

Letters of Queen Elizabeth I. Edited by G.B. Harrison. London: Cassell, 1968.

Medici, Catherine de. Lettres de Catherine de Médicis. Edited by Hector de la Ferrière and Gustave Baguenault de Puchesse. 10 vols. Paris: Imprimerie Nationale, 1880-1943.

Nouvelle collection des mémoires pour servir à l'histoire de France depuis le XIIIe siècle jusqu'à la fin du XVIIIe : François de Lorraine, le prince de Condé. Edited by J. Fr. Michaud and Jean Joseph François Poujoulat.Vol 6. Paris, Chez l'éditeur du commentaire analytique du code civil, 1839.

Papal Negotiations with Mary Queen of Scots during her Reign in Scotland: 1561-1567. Edited by John Hungerford Pollen. Edinburgh, Printed at the University Press by T. and A. Constable, for the Scottish History Society, 1901.

Paschal, Pierre de. Journal de ce qui s'est passé en France durant l'année1562, principalement dans Paris et à la cour. Edited by Petrus Paschalius, Michel Franc $\square$ ois, and Pierre Champion. Paris, H. Didier, 1950.

Pasquier, Estienne. Lettres Historiques: Pour les années 1556-1594. Edited by D. Thickett. Geneva: Libraire Droz, 1966.

Relations politiques de la France et de l'Espagne avec l'Ecosse au XVIe siècle. Edited by Jean Baptiste Alexandre Théodore Teulet. Paris: Veuve J. Renouard, 1862.

Suriano, Michele and Marc' Antonio Barbaro. Despatches of Michele Suriano and Marc' Antonio Barbaro, 1560-1563. Edited by Sir Austen Henry Laylard. Vols 2. Lymington, UK: Huguenot Society of London, 1891. 
Valois, Marguerite de. Memoirs of Marguerite de Valois, Queen of France, Wife of Henri IV of Madame de Pompadour of the Court of Louis XV and of Catherine de Medici, Queen of France, Wife of Henri II: With a Special Introduction and Illustriations. Edited by Marguerite du Hausett. Vol. 1. New York, NY: P.F. Collier \& Son, 1910.

Valois, Marguerite de. Correspondance: 1569-1614. Edited by Eliane Viennot. Paris: Honoré Champion Editeur, 1998. 


\section{$\underline{\text { Secondary Sources }}$}

Baillon, Charles, comte de. Histoire de Louise de Lorraine : Reine de France, 1553-1601. Paris: Chez Léon Techener, 1884.

Baker, Joanne. "Monasticism and Family Strategy: The Guises and Saint Pierre de Reims." The Sixteenth-Century Journal 28, 4 (Winter 1997): 1091-1108.

Bayle, Pierre. Dictionnaire historique et critique de Pierre Bayle. Edited by Jaques George de Chaufepié et al. Vol. 13. Paris: Desoer, 1820. http://books.google.com/books?id=D2V6QT2H4JI $\mathrm{C} \& p g=\mathrm{PA} 448 \& \mathrm{dq}=$ Dictionnaire+historique $+\mathrm{et}+$ critique $+\mathrm{de}+\mathrm{Pierre}+$ Bayle + volume $+13+1820 \& \mathrm{~h}$ $\mathrm{l}=$ en\&ei=Oou3TZqSAuTv0gGa_O3WDw\&sa=X\&oi=book_result\&ct=book-thumbnail\&resn $\mathrm{um}=2 \& \mathrm{ved}=0 \mathrm{CDEQ} 6 \mathrm{wEwAQ} \# \mathrm{v}=$ onepage $\& \mathrm{q}=$ renaud $\% 20 \mathrm{de} \% 20 \mathrm{beaune} \& \mathrm{f}=\mathrm{false}$.

Bersier, Eugène. Coligny: The Earlier Life of the Great Huguenot. London: Hodder and Stoughton, 1884.

Chapman, Sara. "Patronage as Family Economy: The Role of Women in the Patron-Client Network of the Phelypeaux de Pontchartran Family." French Historical Studies 24, 1 (Winter 2001): 11-35.

Carroll, Stuart. Martyrs and Murders: The Guise Family and the Making of Europe. Oxford, Oxford University Press, 2009.

- Noble Power during the French Wars of Religion: The Guise Affinity and the Catholic Cause in Normandy. Cambridge: Cambridge University Press, 1998.

Chéruel, Adolphe. Marie Stuart et Catherine de Médicis. Paris: Hachette, 1858.

Clément, Chantal. Louise de Lorraine-Vaudémont, reine de France. Guilherand Granges, FR: Plume du temps, 2002.

Cloulas, Ivan. Catherine de Médicis. Paris: Fayard, 1979.

Constant, Jean-Marie. Les Guises. Paris: Hachette, 1984.

Crawford, Katherine. "Catherine de Medici and the Performance of Political Motherhood." The Sixteenth Century Journal 31, 3 (Autumn 2000): 643-673.

- Perilous Performances: Gender and Regency in Early Modern France. Cambridge, MA: Harvard University Press, 2004.

Desjardins, Abel. Charles IX : Deux Années de Regne, 1570-1572. Paris: Douai, 1873.

Dreux du Radier, Jean-François. Mémoires historiques, critiques, et anecdotes des reines et régentes de France. Paris, De L'imprimerie des Frères Mame, 1808. 
Édouard, Sylvène. Le corps d'une reine: Histoire singulière d'Élisabeth de Valois, 1546-1568. Rennes: Presses Universitaires de Rennes, 2009.

Fichtner, Paula Sutter. Maximilian II. New Haven, CT: Yale University Press, 2001.

Frieda, Leonie. Catherine de Medici: Renaissance Queen of France. New York, NY: Harper Collins Publishers Inc., 2003.

Harkrider, Melissa Franklin. Women, Reform and Community in Early Modern England: Katherine Willoughby, Duchess of Suffolk. Woodbridge, Rochester, NY: Boydell Press, 2008.

Harris, Barbara J. English Aristocratic Women, 1450-1550: Marriage and Family, Property and Careers. Oxford, UK: Oxford University Press, 2002.

—. "Sisterhood, Friendship and the Power of English Aristocratic Women, 1450-1550." In Women and Politics in Early Modern England, 1450-1700, edited by James Daybell, 21-50. Aldershot, UK: Ashgate: 2004.

Hodson, Simon. "The Power of Female Dynastic Networks: A Brief Study of Louise de Coligny, Princess of Orange, and her Stepdaughters.” Women's History Review 16, 3 (July 2007): 335351.

Holt, Mack P. The Duke of Anjou and the Politique Struggle during the Wars of Religion. Cambridge, UK: Cambridge University Press, 2002.

- "Patterns of Clientele and Economic Opportunity at Court During the French Wars of Religion: The Household of François, Duke of Anjou." French Historical Studies 13, 3 (Spring 1984): 305-322.

Hoogvliet, Margriet. "Princely Culture and Catherine de Médicis." In Princes and Princely Culture, 1450-1650, edited by Martin Gosman, Alasdair MacDonald, and Arie Johan Vanderjagt, 103-130. Vol. 1. Leiden and Boston: Brill, 2003.

Ives, Eric. The Life and Death of Anne Boleyn. Malden, MA: Wiley-Blackwell, 2005.

King, John H. "Patronage and Piety: Catherine Parr." In Silent but for the Word: Tudor Women as Patrons, Translators, and Writers of Religious Works, edited by Margaret P. Hannay, 43-60. Kent, OH: Kent State University Press, 1985.

Knecht, R.J. Catherine de' Medici. New York, NY: Longman, 1998.

Kettering, Sharon. "The Household Service of Early Modern French Noblewomen." French Historical Studies 20, 1 (Winter 1997): 55-85.

_. "The Patronage and Power of Early Modern French Noblewomen." The Historical Journal 32, 4 (December 1989): 817-841. 
Le Roy Ladurie, Emmanuel. The Peasants of Languedoc. Champaign, IL: University of Illinois Press, 1977.

Mears, Natalie "Politics in the Elizabethan Privy Chamber: Lady Mary Sidney and Kat Ashley." In Women and Politics in Early Modern England, 1450-1700, edited by James Daybell, 67-82. Aldershot, UK: Ashgate, 2004.

Munns, Jessica and Penny Richards. "Exploiting and Destabilizing Gender Roles: Anne d'Este." French History 6, 2 (1992): 159-184.

Neuschel, Kristen B. "Noblewomen and War in Sixteenth-Century France." In Changing Identities in Early Modern France, edited by Michael Wolfe, 24-44. Durham, NC: Duke University Press, 1997.

Oresko, Robert "The Marriages of the Nieces of Cardinal Mazarin: Public Policy and Private Strategy in Seventeenth-Century Europe." In Frankreich im Europäischen Staatensystem der Frühen Neuzeit, edited by Rainer Babel, 109-151. Sigmaringen, DE: Jan Thorbecke Verlag, 1995.

Parker, Geoffrey. The Grand Strategy of Philip II. New Haven, CT and London: Yale University Press, 1998.

Payne, Helen. "Aristocratic Women, Power, Patronage and Family Networks at the Jacobean Court, 1603-1635." In Women and Politics in Early Modern England, 1450-1700, edited by James Daybell, 164-180. Aldershot: Ashgate, 2004.

Pitts, Vincent J. Henri IV of France: His Reign and Age. Baltimore, MD: The John Hopkins University Press, 2009.

Ribera, Jean-Michel. Diplomatie et Espionnage: Les ambassadeurs du roi de France auprès de Philippe II du traité du Cateau-Cambresis (1559) a la mort de Henri III (1589). Paris: Honoré Champion Éditeur, 2007.

Richards, Penny. "The Guise Women: Politics, War and Peace." In Gender, Power and Privilege in Early Modern Europe, edited by Jessica Munns and Penny Richards, 159-170. Harlow, UK: Pearson Education Limited, 2003.

Roelker, Nancy Lyman. "Appeal of Calvinism to French Noblewomen in the Sixteenth Century.” Journal of Interdisciplinary History 2, 4 (Spring 1972): 391-418.

- Queen of Navarre: Jeanne d'Albret, 1528-1572. Cambridge, MA: Belknap Press of Harvard University Press, 1968.

Ruble, Alphonse de. Antoine de Bourbon et Jeanne d'Albret : suite du mariage de Jeanne d'Albret. Paris: A. Labitte, 1886. 
Sánchez, Magdalena S. The Empress, the Queen, and the Nun: Women and Power at the Court of Philip III of Spain. Baltimore, MD: Johns Hopkins University Press, 1998.

Simonin, Michel. Charles IX. Paris: Fayard, 1995.

Sutherland, N.M. "Antoine de Bourbon, King of Navarre and the French Crisis of Authority, 1559-1562." In Princes, Politics and Religion: 1547-1589, edited by N.M. Sutherland, 55-72. London, UK: Hambledon Press, 1984. Originally published in J.F. Bosher, ed. French Government and Society: Essays in Memory of Alfred Cobban (London, UK: Athlone Press, 1973).

- The French Secretaries of State in the Age of Catherine de Medici. London: University of London, the Athlone Press, 1962.

—. "Catherine De Medici: The Legend of the Wicked Italian Queen." The Sixteenth Century Journal 9, 2 (July 1978): 45-56.

Strong, Roy C. Art and Power: Renaissance Festivals, 1450-1650. Berkeley, CA: University of California Press, 1984.

Van Dyke, Paul. Catherine de Médicis. New York, NY: Charles Scribner's Sons, 1922.

Vester, Matthew A. Jacques de Savoie-Nemours: L'apanage du Genevois au cour de la puissance dynastique savoyarde au XVIe siècle. Translated by Eléonore Mazel and Déborah Engel. Genève: Droz, 2008.

Viennot, Eliane. Marguerite de Valois: Histoire d'une femme, histoire d'un mythe. Paris: Grande Bibliothèque Payot, 1995.

Weir, Alison. Mary, Queen of Scots and the Murder of Lord Darnley. New York, NY: Ballatine Books, 2009.

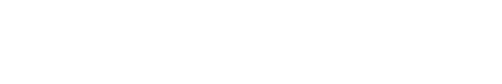 Hagen actis}

